\begin{tabular}{|c|c|c|c|}
\hline & НАУЧНО-ТЕХНИЧЕСКИЙ ВЕСТНИК ИН & РМАЦИОННЫХ ТЕХНОЛОГИЙ, МЕХАНИКИ И ОПТИКИ & \\
\hline 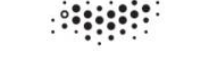 & $\begin{array}{l}\text { январь-февраль } 2017 \quad \text { Том } 17 \text { № } 1 \\
\text { SCIENTIFIC AND TECHNICAL JOURNAL O }\end{array}$ & $\begin{array}{l}\text { ISSN 2226-1494 } \\
\text { IFORMATION TECHNOLOGIES, MECHANICS AND OPTICS }\end{array}$ & 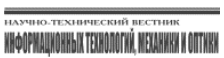 \\
\hline УНИВЕРСИТЕТ ИТМО & January-February 2017 & http://ntv.ifmo.ru/en & \\
\hline
\end{tabular}

\title{
NANOSCALE STRUCTURES GENERATION WITHIN THE SURFACE LAYER OF METALS WITH SHORT UV LASER PULSES
}

\author{
D.S. Ivanov ${ }^{a, b, c}$, A. Blumenstein ${ }^{\text {d,a }}$, B. Rethfeld ${ }^{\text {b }}$, V.P. Veiko ${ }^{c}$, E.B. Yakovlev ${ }^{c}$, M.E. Garcia ${ }^{a}$, \\ P. Simon ${ }^{\mathrm{d}}$, J. Ihlemann ${ }^{\mathrm{d}}$
}

${ }^{\text {a }}$ University of Kassel, Kassel, 34132, Germany

b Department of Physics and OPTIMAS research center, Technical University of Kaiserslautern, Kaiserslautern, 67663, Germany

${ }^{\mathbf{c}}$ ITMO University, Saint Petersburg, Russian Federation

d Laser-Laboratorium-Göttingen e.V., Göttingen, 37077, Germany

Corresponding author: ivanov@uni-kassel.de

\section{Article info}

Received 16.10.16, accepted 10.12.16

doi: 10.17586/2226-1494-2017-17-1-1-15

Article in English

For citation: Ivanov D.S., Blumenstein A., Rethfeld B., Veiko V.P., Yakovlev E.B., Garcia M.E., Simon P., Ihlemann J. Nanoscale structures generation within the surface layer of metals with short UV laser pulses. Scientific and Technical Journal of Information Technologies, Mechanics and Optics, 2017, vol. 17, no. 1, pp. 1-15. doi: 10.17586/2226-1494-2017-17-1-1-15

\section{Abstract}

We have completed modeling of a laser pulse influence on a gold target. We have applied a hybrid atomistic-continuum model to analyze the physical mechanisms responsible for the process of nanostructuring. The model combines the advantages of Molecular Dynamics and Two Temperature Model. We have carried out a direct comparison of the modeling results and experimental data on nano-modification due to a single ps laser pulse at the energy densities significantly exceeding the melting threshold. The experimental data is obtained due to a laser pulse irradiation at the wavelength of 248 $\mathrm{nm}$ and duration of $1.6 \mathrm{ps}$. The mask projection (diffraction grating) creates the sinusoidal intensity distribution on a gold surface with periods of $270 \mathrm{~nm}, 350 \mathrm{~nm}$, and $500 \mathrm{~nm}$. The experimental data and modeling results have demonstrated a good match subject to complex interrelations between a fast material response to the laser excitation, generation of crystal defects, phase transitions and hydrodynamic motion of matter under condition of strong laser-induced non-equilibrium. The performed work confirms the proposed approach as a powerful tool for revealing the physical mechanisms underlying the process of nanostructuring of metal surfaces. Detailed understanding of the dynamics of these processes gives the possibility for designing the topology of functional surfaces on nano- and micro-scales.

Keywords

UV laser pulses, nanostructuring, simulations, molecular dynamics

\section{Acknowledgements}

The reported study was supported partially by the Ministry of Education and Science of Russia, research agreement No.14.578.21.0197 (RFMEFI57816X0197, by RFBR grant No. 14-29-07227 OFI-M, and the Government of the Russian Federation Grant No. 074-U01, and DFG grants IV 122/1-1, IV 122/1-2, and IH 17/18-1. The authors acknowledge the Lichtenberg Super Computer Facility (Darmstadt, Germany) team for the technical support provided for super large scale parallel simulations.

\section{УДК 538.913, 53.01, 519.6 \\ ОБРАЗОВАНИЕ НАНОРАЗМЕРНЫХ СТРУКТУР В ПРИПОВЕРХНОСТНОМ СЛОЕ МЕТАЛЛОВ ПРИ ВОЗДЕЙСТВИИ УЛЬТРАКОРОТКОГО ЛАЗЕРНОГО ИМПУЛЬСА УЛЬТРАФИОЛЕТОВОГО ДИАПАЗОНА}

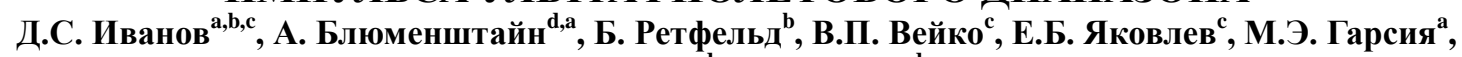
П. Симон

${ }^{\text {a } У н и в е р с и т е т ~ К а с с е л я, ~ К а с с е л ь, ~ 34132, ~ Г е р м а н и я ~}$

b Отделение Физики и Исследовательский Центр ОПТМАТ, Технический Университет Кайзерслаутерна, Кайзерслаутерн, 67663, Германия

с Университет ИТМО, Санкт-Петербург, 197101, Российская Федерация

d Лазерная лаборатория Гёттингена, Гёттинген, 37077, Германия

Адрес для переписки: Ivanov@uni-kassel.de

Информация о статье

Поступила в редакцию 16.10 .16 , принята к печати 10.12 .16

doi: 10.17586/2226-1494-2017-17-1-1-15

Язык статьи - английский 
Ссылка для цитирования: Иванов Д.С., Блюменштайн А., Ретфельд Б., Вейко В.П., Яковлев Е.Б., Гарсия М.Э., Симон П., Илеман Ю. Образование наноразмерных структур в приповерхностном слое металлов при воздействии ультракороткого лазерного импульса ультрафиолетового диапазона // Научно-технический вестник информационных технологий, механики и оптики. 2017. Т. 17. № 1. C. 1-15. doi: 10.17586/2226-1494-2017-17-1-1-15

\section{Аннотация}

Выполнено моделирование воздействия лазерного импульса на золотую мишень. С этой целью применена гибридная модель, сочетающая молекулярную динамику и анализ на основе непрерывной (континуальной) двухтемпературной модели, способная проанализировать механизмы, ответственные за процесс наноструктурирования. Проведено прямое сравнение данных моделирования и экспериментальных результатов по наномодификации поверхности одним лазерным импульсом пикосекундной длительности при плотностях энергии, значительно превышающих порог плавления. Экспериментальные результаты получены при воздействии лазерного излучения с длиной волны 248 нм и длительностью импульса 1,6 пс. Проекция маски (дифракционной решетки) на поверхность золота создает распределение интенсивности синусоидальной формы с периодом 500 нм. Продемонстрировано хорошее совпадение экспериментальных данных с результатами моделирования с учетом сложных связей между сверхбыстрым откликом материала на лазерное возбуждение, генерацией кристаллических дефектов, фазовыми превращениями и массопереносом, протекающими в сильнонеравновесных условиях. Выполненная работа подтверждает, что предлагаемый подход может стать мощным инструментом выявления физических процессов наноструктурирования поверхности металлов. Детальное понимание динамики процесса дает возможность разрабатывать топологии функциональных поверхностей на нано- и микромасштабах.

\section{Ключевые слова}

УФ лазерные импульсы, наноструктурирование, моделирование, молекулярная динамика

\section{Благодарности}

Работа выполнена при поддержке Министерства образования и науки Российской Федерации, соглашение №14.578.21.0197 (RFMEFI57816Х0197), а также гранта РФФИ № 14-29-07227 ОФИ-М, субсидии Правительства Российской Федерации № 074-U01 и грантов DFG IV 122/1-1, IV 122/1-2 и IH 17/18-1. Авторы благодарят обслуживающий персонал Суперкомпьютера Лихтенберг (Дармштадт, Германия) за оказанную техническую поддержку в процессе сверхмассивных параллельных вычислений.

\section{Introduction}

The growth of ultrashort pulse laser technologies has opened up new opportunities for high-precision processing of a wide range of materials, including dielectrics, semiconductors, and metals, thus, enabling numerous practical applications in the fields ranging from micromachining to photonics and life sciences [1-3]. The ability of ultrashort lasers to deposit energy into a much localized volume of the irradiated target makes it possible to perform very selective material modification and, at the same time, provides unique opportunities for investigating material behavior and properties under extreme conditions of strong electronic excitation, rapid heating and cooling, and ultrafast laser-induced mechanical deformation. This can result in the formation of unique structures in a pre-surface layer of a material affected by the laser deposition [1-3].

The initial non-thermal material response to the ultrafast laser excitation is quick, within picoseconds, followed by the onset of thermal processes induced by the energy transfer from the excited electrons to atomic vibrations, commonly described as electron-phonon coupling. The rapid electron-phonon equilibration can produce ultrafast heating rates exceeding $10^{14} \mathrm{~K} / \mathrm{s}$, providing, therefore, opportunities for investigation of the kinetic limits of achievable superheating of solid phases. Indeed, a combination of time-resolved optical, X-ray and electron diffraction probing of short pulse laser melting [4-6] with theoretical analysis and Molecular Dynamics (MD) simulations [7, 8] has provided important information on the time-scales and mechanisms of the melting process occurring under conditions of strong superheating. However, the short pulse laser irradiation may cause not only the rapid heating and melting of localized surface or internal regions of the target, but also produce sharp temperature gradients leading to a rapid quenching of the transiently melted material. In strongly absorbing materials, such as metals or semiconductors, a combination of shallow depth of the laser energy deposition with high thermal conductivity of the irradiated material can lead to cooling rates approaching $10^{12} \mathrm{~K} / \mathrm{s}$. The cooling rates can be even higher, in excess of $10^{13} \mathrm{~K} / \mathrm{s}$ [9], when the laser energy deposition is confined not only within the thin surface layer of the irradiated target but also in the lateral dimensions, creating conditions for even faster two- or three-dimensional heat transfer from the absorption region. The laterally localized laser energy deposition can be achieved by using tightly focused laser beams [10-11] or taking advantage of the local field enhancement in the vicinity of a tip of a scanning probe microscope [12, 13]. Since the number of highly non-equilibrium interrelated processes above can be involved into the material response to a short laser pulse irradiation and since those processes can take place on a wide spatial and time scales, it can be difficult, or sometimes impossible, to treat the obtained experimental data with a definite confidence.

In this context, due to its microscopic approach, the MD-based modeling was found to be an efficient numerical tool for the theoretical investigation of ultrafast non-equilibrium laser induced processes in materials. Recently, with the combined atomistic-continuum model [14], the kinetics of the induced phase transition processes is addressed at an atomic level with the MD method. At the same time, the processes of laser light absorption by conduction band electrons, fast electron-heat conduction, and generated strong electron-phonon non-equilibrium are described in the continuum with the help of the Two Temperature Model (TTM) [15]. This combined atomistic-continuum MD-TTM model [14] was successfully used in studying short pulse laser 
induced melting, spallation, and ablation of thin and thick metal targets [16-18].

This work is a continuation of our previously published results $[19,20]$, where the mechanism of periodic nanostructuring process was studied both experimentally and theoretically with UV (248 nm) single laser pulses (with a periodic sinusoidally-shaped spatial intensity profile on the surface of a thick Au target) with the fluences just above the damage threshold. In the present work, however, the applied incident fluences ranged from near to significantly above the damage threshold valuing of 125,160 , and $250 \mathrm{~mJ} / \mathrm{cm}^{2}$. Experiments and simulations are executed with the same spatial laser intensity period of $270 \mathrm{~nm}$. The spatial irradiation geometry of the experiment combined with a properly selected model volume gives the opportunity to obtain a direct comparison of experiment and simulation of nanostructuring of a thick Au target.

To obtain smaller structures, the use of ultrashort UV pulses instead of visible light pulses is advantageous since the shorter wavelength allows a far better spatial resolution. Meanwhile, the use of pulse length shorter than the characteristic electron-phonon relaxation time of the material (about $25 \mathrm{ps}$ for gold at the fluencies near the melting threshold $[21,22]$ ) allows for a complete deposition of the pulse energy in the electronic system before transferring it to the lattice, thus ensuring highly localized material modifications [23]. For the generation of deterministic sub-micron periodic patterns various irradiation concepts have been demonstrated. The required interference of two or more beams has been accomplished by mask projection [24], a two grating interferometer [25], or a proximity phase mask set-up [26]. A wide range of applications through optimized light coupling in photovoltaic [27], Light Emitting Diodes (LED) [28], and detector devices [29] can benefit from the gained knowledge and allow a detailed control of the fabrication process of next generation devices.

\section{The Experiment}

Similarly to $[19,20]$, all surface structuring experiments are accomplished by single pulse exposure using a combination of interference and mask projection to form a large area sinusoidal intensity distribution on the sample surface (Fig. 1). The applied two-beam interference (resulting in the sinusoidal pattern) allows reaching the highest possible spatial intensity gradient, crucial for keeping the simulated volume as small as possible. The smallest available modulation period $d$ is then only limited by the numerical aperture (NA) of the applied optics and the laser wavelength $\lambda$ and can be expressed as $d=\lambda / 2 \mathrm{NA}$. Thus, using a short wavelength of $248 \mathrm{~nm}$ and a large numerical aperture of $\mathrm{NA}=0.4$, a lower limit for the periodicity of approximately $270 \mathrm{~nm}$ is obtained (as compared to our previous experiments $310 \mathrm{~nm}$ ). The used laser system consists of a frequency tripled Ti:Sa system seeding a KrF excimer amplifier producing pulse energies of up to $30 \mathrm{~mJ}$ at a wavelength of $248 \mathrm{~nm}$ and a repetition rate of $10 \mathrm{~Hz}$. The pulse length of $1.6 \mathrm{ps}$ is measured by using a frequency resolved optical gating (FROG) trace obtained with a device described in [30]. Single pulses are selected by a shutter. The used pulse energy is set by a variable attenuator. The flat top central part of the laser beam illuminates the mask comprising a circular aperture of $1 \mathrm{~mm}$ diameter in contact with a Cr-on-quartz grating of lines and spaces with $25 \mu \mathrm{m}$ period and duty cycle 0.5. The demagnification of the Schwarzschild-objective used for mask imaging is adjusted to be $25^{\times}$. Consequently, the diameter of the overall projected area on the workpiece is $40 \mu \mathrm{m}$. Since all diffracted orders emerging from the transmission grating except the two first orders are blocked, the image is formed via two-beam interference, resulting in a sinusoidal intensity distribution across the $40 \mu \mathrm{m}$ area. A schematic view of this distribution is shown in Fig. 1, b. The resulting structures, obtained with the experimental set-up described above, can be seen as Scanning Electron Microscopy (SEM) images in Fig. 2 for different incident fluences. The presented images reveal the periodic frozen structures with difference aspect ratio depending on the applied fluence. One can also see that with the increase of fluence, the number of opened voids to the surface grows as well. The mechanism of these periodic structures formation, generation and evolution of voids, and the microstructures character will be investigated with an advance theoretical approach described below in the next section.

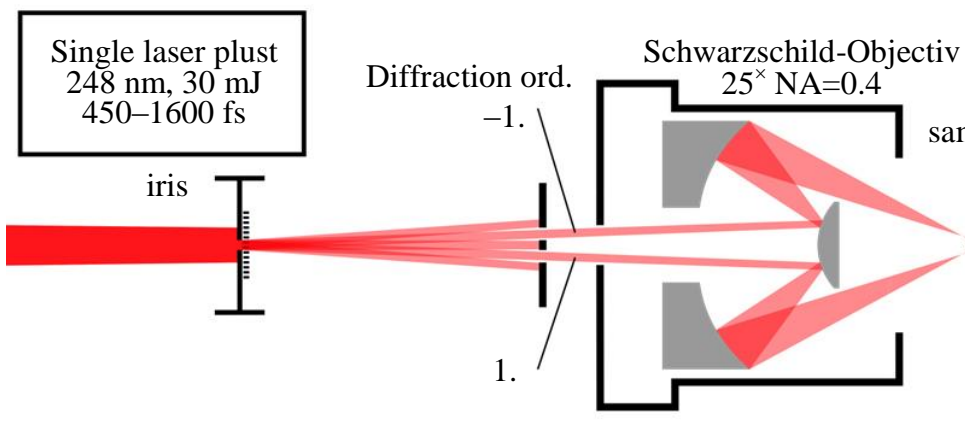

a

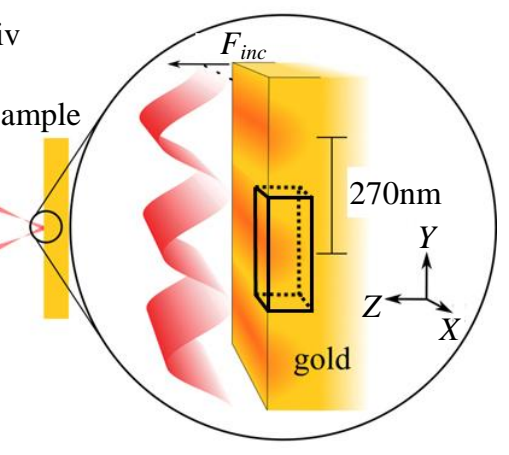

$\mathrm{b}$

Fig. 1. Mask projection setup for a periodic surface structuring of an area of $40 \mu \mathrm{m}$. A sinusoidal interference pattern with a period of $270 \mathrm{~nm}$ is obtained by using only the $\pm 1^{\text {st }}$ diffraction orders (a). Schematic shape of the incident fluence distribution $\left(F_{\text {inc }}\right)$ created by an ideal single laser pulse self-interference of two beams under a certain angle (b) 


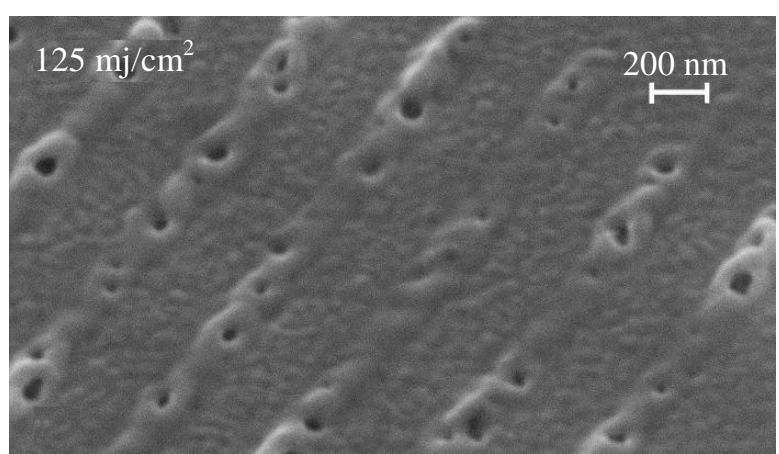

a

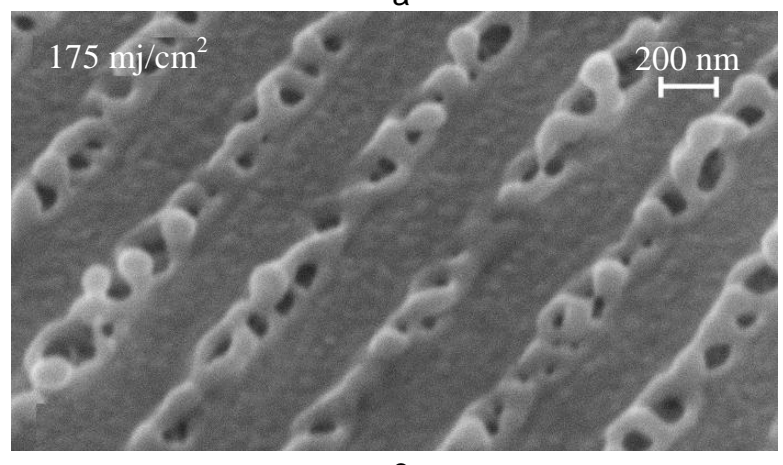

C

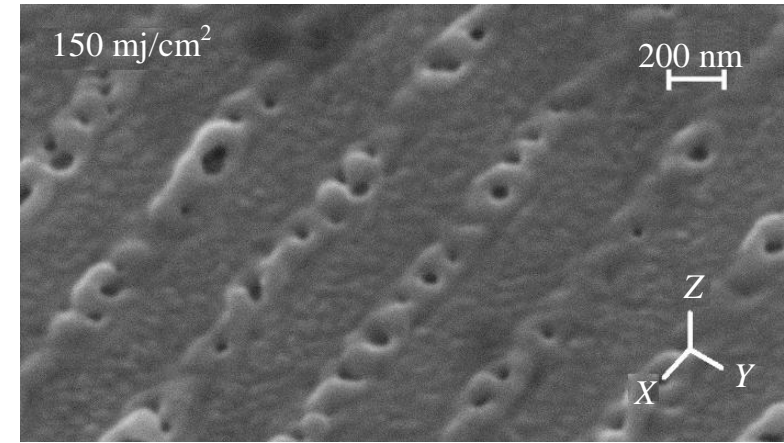

$\mathrm{b}$

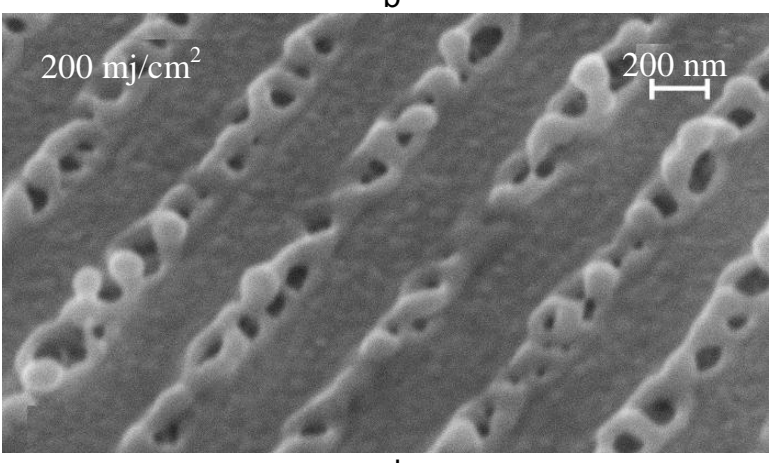

d

Fig. 2. SEM pictures showing surface modifications from a single laser pulse with periodic line spacing of $270 \mathrm{~nm}$ corresponding to the periodic irradiation pattern created by two beam interference for the incident fluences of $125 \mathrm{~mJ} / \mathrm{cm}^{2}$ (a), $150 \mathrm{~mJ} / \mathrm{cm}^{2}$ (b), $175 \mathrm{~mJ} / \mathrm{cm}^{2}$ (c), and $200 \mathrm{~mJ} / \mathrm{cm}^{2}$ (d). Small segments of a larger structured area on a thick gold sample at four different average incident fluences are shown. The sample was tilted in the SEM by $45^{\circ}$ relative to the electron beam axis to increase the contrast. The figure is taken from Ref. [19].

\section{The Model}

The essential concepts and applications of the combined atomistic-continuum model MD-TTM to study the evolution of metallic solids excited by an ultrashort laser pulse are described in details in [14]. The model consists of two parts: the atomic motion is described within the MD approach, whereas a diffusion differential equation for electrons is accounting for the effect of free carriers via their temperature dynamics (see Eqs. 3 and 4 in [14]). Thus, the combined model provides a detailed atomic-level description of the kinetics of fast nonequilibrium processes, of laser melting with atomic resolution and, at the same time, in continuum ensures for the adequate description of the laser light absorption by conduction band electrons, the energy transfer to the lattice due to electron-phonon coupling, and the fast electron heat conduction (see Fig. 2 in [14]). Based on the atomistic-continuum approach, the MD-TTM model was further developed for the simulation of nanostructuring processes of metal targets in a multiprocessing algorithm (running in parallel) to be applied in large scale modeling tasks. For the case of modeling nanostructuring of thick metal targets with an UV laser pulse on the experimental scale the model is in details in $[19,20]$, whereas its successful applications for the case of thin targets can be found elsewhere [31, 32].

The schematic view of the total computational cell utilized in the simulation of the nanostructuring process can be seen in Fig. 3. The idea of modeling on the experimental scale is based on symmetry utilization of the experiment described above, see Figs. 1 and 2. The laser beam, sinusoidally shaped in one dimension $(Y)$, leaves a uniform laser intensity distribution in $X$ direction. Dealing with the size of the laser spot of about $40 \mu \mathrm{m}$ in diameter (flat top in $X$ and sinusoidal shaped in $Y$ ), its central part will therefore not be affected by a diffusion process in $X$ direction up to the order of $1 \mu$ s of the experimental time. This estimated time is confirmed in preliminary calculations using the TTM approach [15]. Considering this time as long enough for the formation and solidification of the nanostructures [32], this provides a possibility for Periodic Boundary (PB) conditions in $X$ during our simulation time (up to several ns). As a result, since we do not expect any temperature and pressure gradients in the lateral direction parallel to the grating lines $(X)$, for a simulation allowing for identical comparison with experiment, we constructed the computational cell as schematically shown in Fig. 5. The Au MD supercell consisting of $160,000,000$ atoms was taken with dimensions of $(40 \times 270 \times 200) \mathrm{nm}$ in $X, Y$, and $Z$ directions respectively. In order to avoid unnecessary and expensive MD integrations in deep bulk of the material, at a certain depth from the surface (in $Z$ direction) we impose Non Reflective Boundary (NRB) conditions. Demanded by the investigated physics, the MD-TTM model was applied only above that limit. The NRB conditions were described in [33] and modified in [32] for the case of a nanostructuring experiment. The NRB conditions, however, are transparent for the heat flux, and the ordinary TTM model was solved beyond the 
NRB taking the electron and phonon temperature dynamics into account on a scale up to $50 \mu \mathrm{m}$ away from the irradiated surface. Thus, with the described computational cell we simulate a thick Au target with atomic resolution within $200 \mathrm{~nm}$ from the surface in the assumption that no phase transition would take place beyond the NRB. This assumption was verified in all our simulations.

The characteristic size of liquid nuclei forming during the laser-induced phase transition process and their initial evolution in the development of the liquid phase has been determined in our previous works to be of the order of $10 \mathrm{~nm}[18,31,32]$. For the applied fluence regime therefore, we consider the width of $40 \mathrm{~nm}$ in $X$ for the slice of modeled material big enough for a safe application of the PB conditions in that direction. A Free Boundary (FB) is imposed at the top, where the material is irradiated with a laser pulse. Finally, we impose PB in $Y$ direction with the size of MD-TTM domain equal to the period of the sinusoidal pulse shape. In essence, it does not matter where the pulse is centered with respect to the MD domain in $Y$ direction. For convenience, we adjust the maximum peak of the laser intensity to the central point of the sample in $Y$ direction. The subsequent multiple translation of this distribution in $X$ and $Y$ direction will reproduce the intensity profile as it is given by the experimental setup, see Fig. 1.

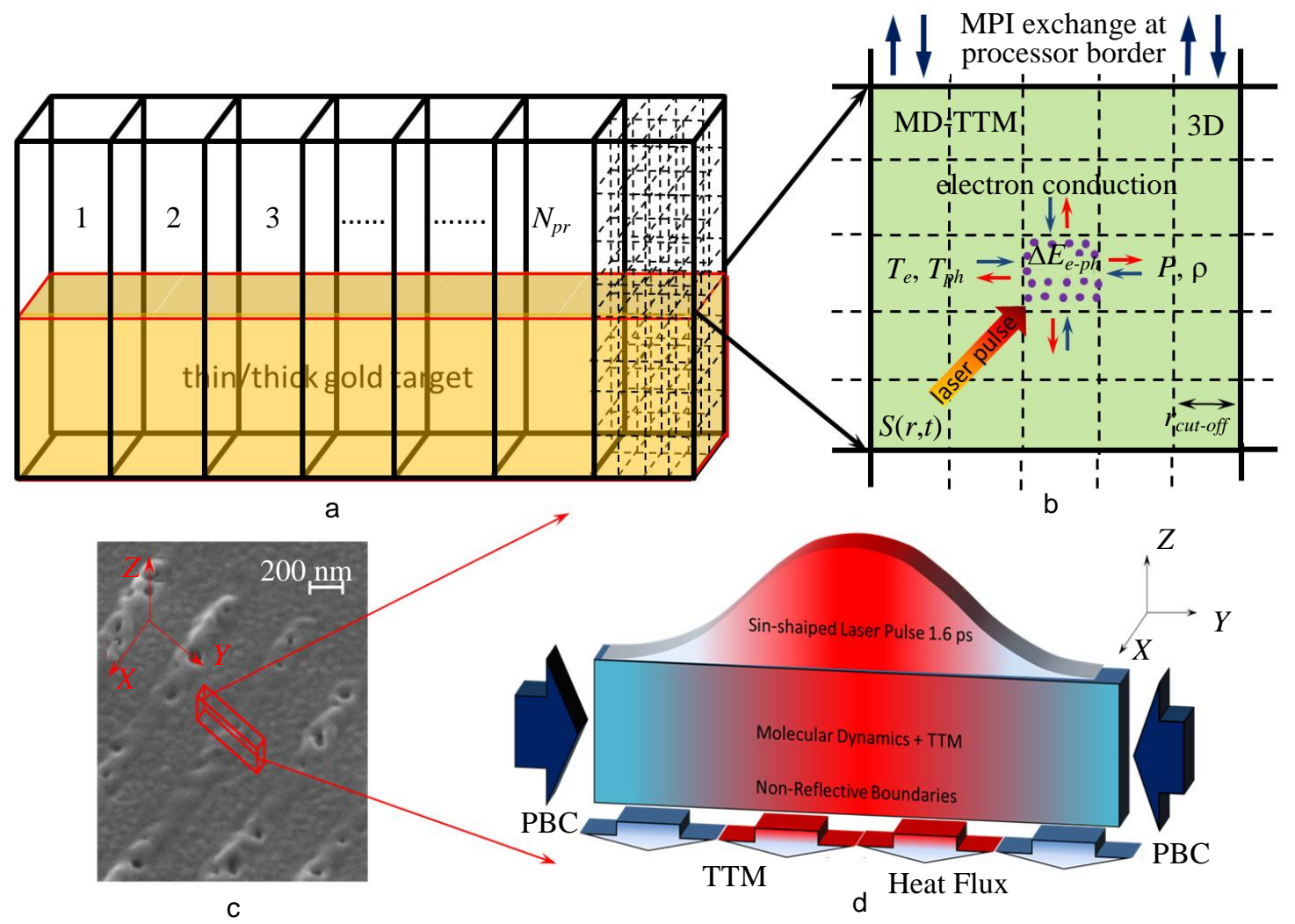

Fig. 3. Schematic representation of the total computational cell divided to the number of processors $N_{\text {proc }}$

(256 in this modeling in $Y$ direction) with utilization of the Message Passing Interface (MPI) library (a). In each processor geometry, a combined atomistic-continuum model MD-TTM was realized in 3D-space (based on cut-off distance of the interatomic potential $r_{\text {cut-off }}$ ) subject to find the temperatures of electrons $T_{e}$ and phonons $T_{p h}$, pressure $P$, and density $\rho$ for a given laser source $S(r, t)$, where $r$ is the position in space and $t$ is time. The energy exchange between electrons and phonons $\Delta E_{e-p h}$ is accounted for in the model each MD time step. (b). SEM picture (Fig. 2, a) of periodic nanostructures on $\mathrm{Au}$ (c) and schematic representation of the computational cell used in the super large scale modeling of this process on the experimental scale (d). PBC are the periodic boundaries. The non-reflective boundaries are transparent for the heat fluxes

The MD-TTM domain was divided into a 3D mesh with $\mathrm{nm}^{3}$ unit cell and the thermo-physical properties of the atomic subsystem (such as temperature and pressure) were averaged over the closest 26 neighboring cells (that totally accounts for about 2,500 atoms) to suppress their value fluctuations due to MD noise [14, 32]. The choice of the mesh size is justified, on one hand, by its minimization for the efficient neighbor list search and calculations of forces in the MD part. On the other hand, the cell must be big enough to accommodate a group of atoms large enough to introduce their statistical description (under assumption of quasi-equilibrium) for a reliable determination of their macroscopic quantities.

In order to have a possibility for the direct comparison of simulation with experiment, the MD-TTM model has implemented a realistic interatomic potential. For this purpose, we choose the Embedded Atom Method (EAM) implementing the interatomic potential by Zhakhovskii et al. [34], optimized for Au. For an 
equilibrium crystal at $P=0 \mathrm{GPa}$ and $T=0 \mathrm{~K}$ the potential gives $-367.609 \mathrm{~kJ} / \mathrm{mol}$ for the cohesive energy, 179.4 $\mathrm{GPa}$ for the bulk modulus, and $0.4065 \mathrm{~nm}$ for the lattice constant. Furthermore, this potential represents the experimental thermophysical properties of the modeled material (such as equilibrium melting temperature, heat capacity, volume of melting, and linear thermal expansion coefficient) with an accuracy of more than $99.5 \%$ [35]. A more detailed description of the model used to describe periodic nanostructuring of metals with UV laser pulse can be found elsewhere $[19,20]$.

Finally, the computational supercell setup, schematically shown in Fig. 3, was run across 256 processors for 30 days resulting in a simulated experimental time of up to $1000 \mathrm{ps}$ of the nanostructuring process for three different applied incident fluences of 125,160 , and $250 \mathrm{~mJ} / \mathrm{cm}^{2}$. In order to perform such a super large-scale simulation, the MPI (Message Passing Interface library) version of the atomistic-continuum model MD-TTM was adopted, optimized, and used as described in [32]. The processors space geometry $1 \times 256 \times 1$ along the $X, Y$, and $Z$ axes was chosen correspondingly for a better load balance during the whole simulation. This choice is governed by our expectation that the laser-assisted material expansion process will proceed upwards and the number of atoms to be processed by each processor therefore will roughly stay the same.

\section{Results and Discussions}

In general, the mechanism responsible for the nanostructuring process is similar to that described in [31] with a simplified model and later confirmed in a super large scale modeling of nanostructuring of thin [32] and thick metal targets $[19,20]$. Namely, the relaxation of the laser-induced compressive stresses generated under conditions of the inertial stress confinement $[16,36]$ serves as the main driving force responsible for the acceleration of a transiently melted region of the target with subsequent bloating of a nanostructure. Fast electron heat conduction, on the other hand, proceeding by two- or three-dimensional mechanism (depending on the experimental geometry), results in the electron temperature falling significantly below the temperature of atoms in the molten volume. In this case, the electrons, due to electron-phonon energy exchange, provide the conditions for the fast cooling of melted material and rapid solidification of a surface feature generated in the process of hydrodynamic motion of the liquid material.

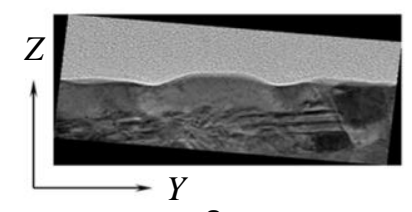

a

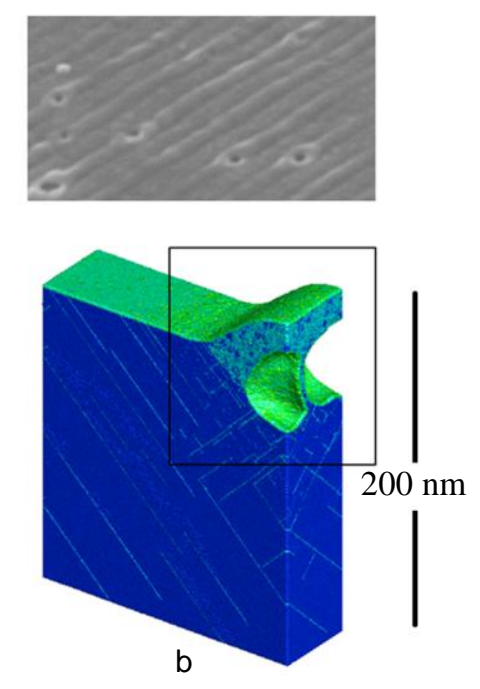

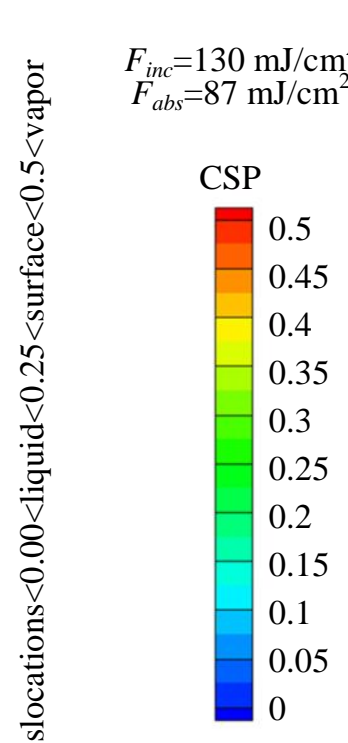

Sample of:

$X=40 \mathrm{~nm}$

$Y=270 \mathrm{~nm}$

$Z=200 \mathrm{~nm}$

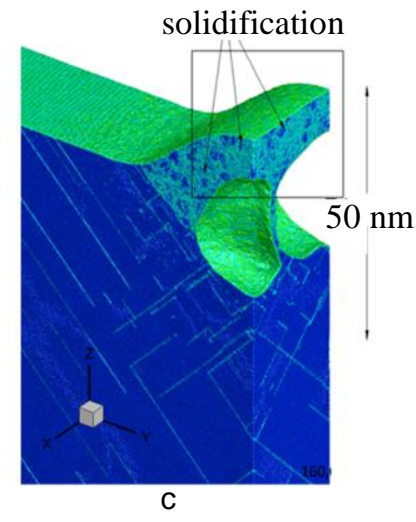

nanocrystalls

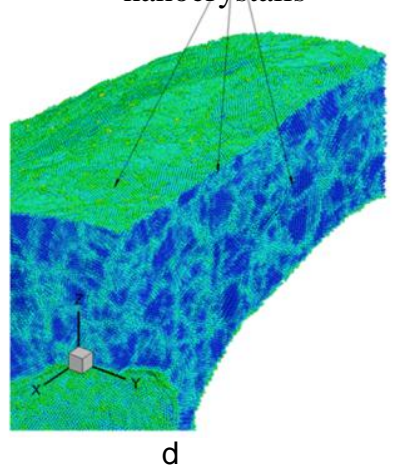

Fig. 4. SEM images of the $270 \mathrm{~nm}$ periodic structures (a) with the incident fluence $F_{\text {inc }}$ of $130 \mathrm{~mJ} / \mathrm{cm}^{2}$ (corresponding to the absorbed fluence $F_{a b s}$ of $87 \mathrm{~mJ} / \mathrm{cm}$ ) are directly compared with the result of an atomistic simulation of the nanostructuring process (b). The atoms are colored with Central Symmetry Parameter (CSP) for distinguishing the atoms with local order (solid - dark blue) from those of disordered structures

(grain boundaries - blue, liquid - light blue, surface green, and vapor - red). The magnified view of the final internal microstructure is shown in (c) and (d)

The snapshots of atomic configurations, shown in Fig. 4, reveal the formation of dislocation planes during the simulations in $\{1,1,1\}$ directions. Being deviated too much from a perfect Face Center Cubic (FCC) crystalline structure, those atoms, characterized by a higher Central Symmetry Parameter (CSP), appear in light 
blue color, still possess a higher order than that in a liquid, shown by blue color. One can conclude that as a result of thermal expansion of the material in response to the fast laser heating, a number of dislocation planes is induced and propagate in the directions with the lowest energy $\{1,1,1\}$ and eventually form stacking faults. The generated stacking faults have a higher energy barrier for further dislocation planes propagation and stop them as a result. In fact, such a stacking fault organization would reinforce the material, working similarly to that described in short pulse laser peening experiments on steel [37-39] and theoretically studied in semiconductor solids [40].

The resulting snapshots presented in Fig. 5 also illustrate a complex interplay of fast laser melting, rapid cooling, resolidification, and relaxation dynamics of laser-induced stresses in the surface region of a gold target during the nanostructuring process at the incident fluence of $160 \mathrm{~mJ} / \mathrm{cm}^{2}$. The monocrystalline layer with ultrafine grains (with the size of less than $5 \mathrm{~nm}$ ) is produced by massive homogeneous nucleation of a solid phase triggered by a deep undercooling of the melted surface region down to below than $0.7 T_{m}$ (below $1000 \mathrm{~K}$ ) and features random crystallographic orientation of nanograins. The enlarged atomic-scale views of the surface microstructure are shown in Fig. 4 and Fig. 5 reveals a high density of stacking faults and nanograins. Because of the higher fluence as compared to that used in Fig. 4, the internal structure includes a number of solidified features inside of the hollow surface nanobarrier. The formation of similar structural elements has also been observed in frozen nano-spikes generated in the spallation regime, in recent MD simulation by Zhigilei et al [41].

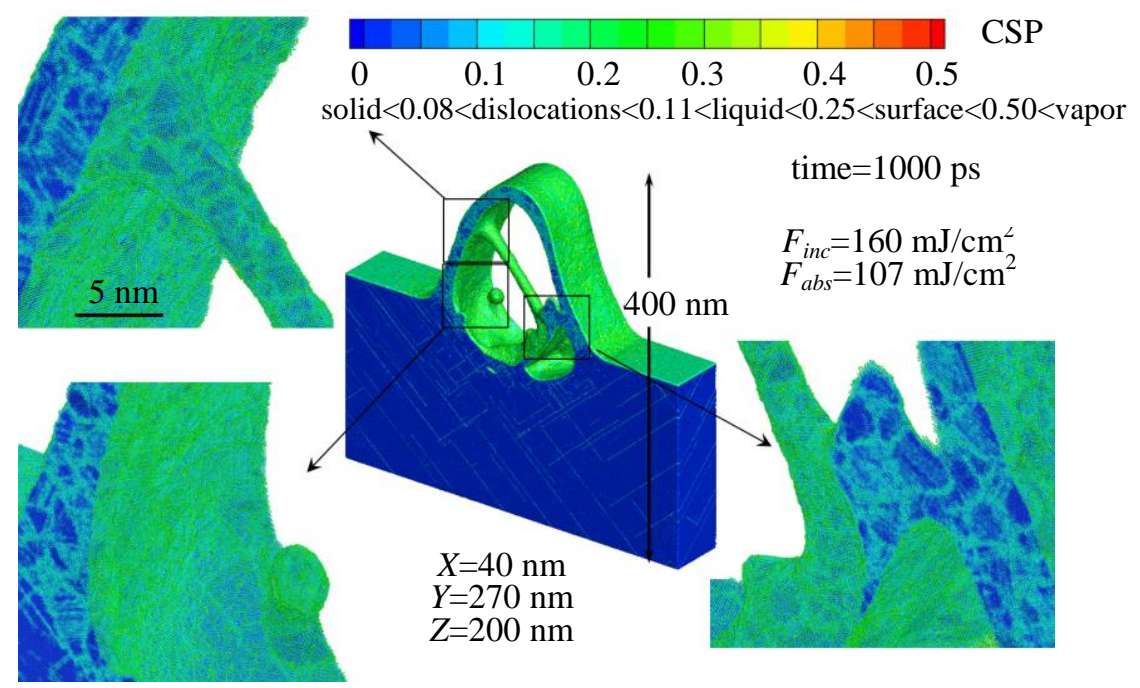

Fig. 5. Atomistic snapshots taken at the end of modeling at $t=1000 \mathrm{ps}$ and obtained in simulation of the periodic nanostructuring process of thick Au target at the incident fluence of $160 \mathrm{~mJ} / \mathrm{cm}^{2}$. Similarly to that of Fig. 4, the atoms are colored according to CSP value. A detailed view on the microscopic structure of the internal structures can be seen in magnified boxes

The computational prediction of the formation of a thin nanocrystalline layer with high density of grains suggests the short pulse laser processing as a viable alternative to the severe plastic deformation [42] or pulsed electrodeposition [43] techniques that are currently employed to yield the maximum structural refinement and high strength of metal samples. Moreover, the localization of the nanocrystalline layer within a thin surface layer (up to about $50 \mathrm{~nm}$ deep) of the target and the prominent presence of grain boundaries are two factors that may also increase the ductility of the laser-modified layer [44-46], a property that is generally incompatible with high strength.

As already mentioned above, the fast rate of energy deposition by short laser pulses may lead to the generation of compressive stresses. The laser-generated stresses are particularly high in the regime of stress confinement $[16,36]$, when the time of the laser heating (defined by the laser pulse duration, $\tau_{p}$, or the time of the electron-phonon equilibration, $\tau_{e-p h}$, whichever is longer) is shorter than the time required for the mechanical relaxation (expansion) of the heated volume, i.e., $\max \left\{\tau_{p}, \tau_{e-p h}\right\} \leq L_{p} / C_{s}$, where $C_{s}$ is the speed of sound in the target material and $L_{p}$ is the effective depth of the laser energy deposition (optical penetration depth or, in the case of metals, the depth of diffusive/ballistic energy transport during the time of the electron-phonon equilibration). The latter can be a function of electron heat conductivity and for the same pulse duration can significantly alter the value of $L_{p}$ depending on the applied fluence [47].

The case of onset of the spallation regime during the nanostructuring process is depicted in Fig. 6 as a sequence of snapshots taken from the simulation with the applied fluence of $250 \mathrm{~mJ} / \mathrm{cm}^{2}$. The relaxation of the laser-induced stresses formed in the material under conditions of inertial stress confinement $[16,36]$ induces strong tensile stresses (about $-4 \mathrm{GPa}$ ) that in the liquid part of the material exceed the material strength (the atmospheric pressure, on the order of $0.1 \mathrm{MPa}$ is a negligible contribution here) and promotes the formation of 
voids, the precursor of a spallation process $[16,17,48,49]$. The mechanism of voids formation was investigated in details for metallic and molecular solids in [16]. It was found that if the conditions for inertial stress confinement are fulfilled under the applied irradiation parameters $[16,17,36]$, the critical size of voids and the rate of their nucleation are governed by the combination of both quantities of the induced tensile forces (negative pressure) and the atomic temperature. The range at which the characteristic temperature and pressure gradients are established by the time of the electron-phonon equilibrium is related to the effective laser energy deposition depth. It was shown that for short laser pulses (shorter than the characteristic electron-phonon equilibration time) this depth can be approximated as a function of the material properties at the applied fluence $[23,36,47,50,51]$. The growth and percolation of the voids may lead to the separation and ejection of a top layer from the target. By analogy with the term "spallation," commonly used to describe the dynamic fracture that results from the reflection of a shock wave from the back surface of a sample, the material ejection driven by the relaxation of the laser-induced stresses is commonly referred to photomechanical spallation. In Fig. 6, one can see that at the highest fluence used in this work, the ejecting material is represented by the pre-surface layer opening to the external ambient and forming the features that were observed in the experiment (Fig. 2, c, d).

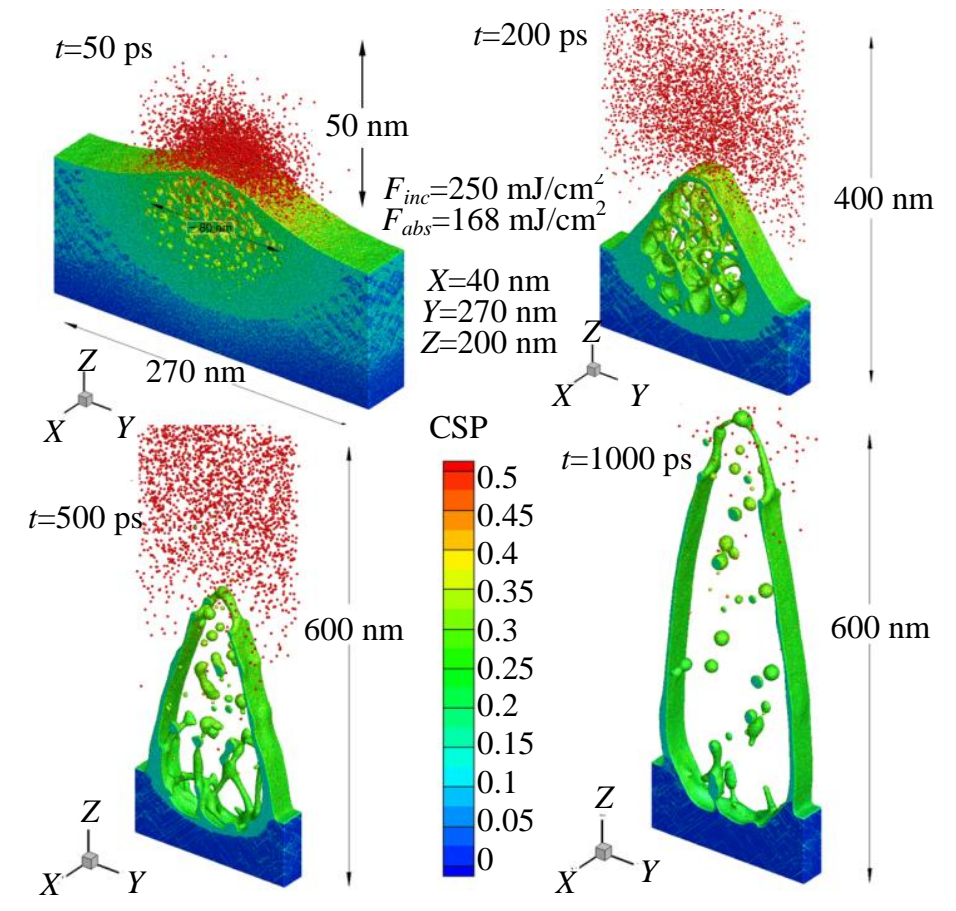

Fig. 6. The sequence of atomic snapshots taken at times 50, 200, 500, and 1000 ps, revealing the dynamics of the nanostructure formation at the fluence $250 \mathrm{~mJ} / \mathrm{cm}^{2}$, that is well above the ablation threshold for Au. The atoms are colored by Central Symmetry Parameter (CSP) parameter

Moreover, due to the spatial variation of laser intensity within laser beams that often have Gaussian profiles, both mechanisms of the material ejection photomechanical (large number of clusters and chunks of the material) and photothermal (large number of vapor particles) may coexist and jointly contribute to the material modification induced by the same laser pulse. This is illustrated in Fig. 6, where a number of free volatile atoms contribute to the total material ejected mass. Thus, both photomechanical and photothermal spallation mechanisms are providing channels for effective transformation of the energy deposited by the laser irradiation into material disintegration and vaporization, thus creating conditions for rapid cooling and freezing of the transient liquid structures generated in laser spallation or ablation. Indeed, the temperature of the liquid-crystal interface is already below the melting temperature of $\mathrm{Au}$ (measured as $T=1000 \mathrm{~K}$ and less than $0.7 T_{m}$ ) by the time of about $600 \mathrm{ps}$, and the interface is moving up, towards the tip of the nanofeature. As a result, the general picture of the nanostructuring experiment at the fluence above the ablation threshold is like to involve the peel off of a continuous liquid layer with its thickness decreasing towards the center of the laser spot, periodically modulated by energy deposition realized in two-beam interference $[19,20]$. Such behavior was also predicted in a mosaic-like reconstruction of the ablation process due to a focused laser spot on silver target presented in [52].

As a result of the presented research, the formation of the final periodic nanostructures on thick Au targets has been investigated both theoretically and experimentally, Fig. 7. In order to simulate the nanostructuring process a hybrid atomistic-continuum (MD-based) super large-scale modeling was applied, which allowed a oneto-one comparison with experiment. The corresponding experimental results were obtained producing an intensity grating on a gold surface with a sinusoidal shape, using single UV-femtosecond laser pulses [19]. The 
final surface structures were investigated by SEM while the preparation of a TEM cross section allowed a detailed look beneath the surface. The high resolution of the latter technique allowed a direct comparison of the experiment with the results of MD simulation on an atomic scale showing a very good agreement. In Fig. 7, a, one can see that at the applied fluence of $130 \mathrm{~mJ} / \mathrm{cm}^{2}$ the resulting snapshot from the atomic simulation reveals an empty space beneath the surface, that corresponds to the lighten area (platinum) obtained by FIB technique upon the post experimental treatment of the gold sample. Fig. 7, b, predicts the formation of large number of monocrystalline structures inside the pre-surface void at the applied fluence of $160 \mathrm{~mJ} / \mathrm{cm}^{2}$. And, finally, the highest applied fluence of $250 \mathrm{~mJ} / \mathrm{cm}^{2}$ (Fig. 7, c), leads to a separation of a thin layer, which opens up to the surface and, simultaneously with the solidification process, forms the closing nanowalls on the sample surface.

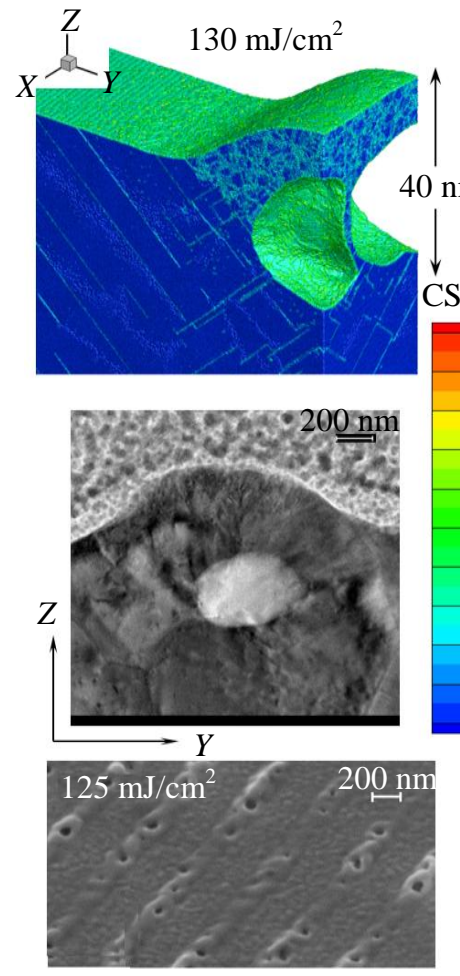

a

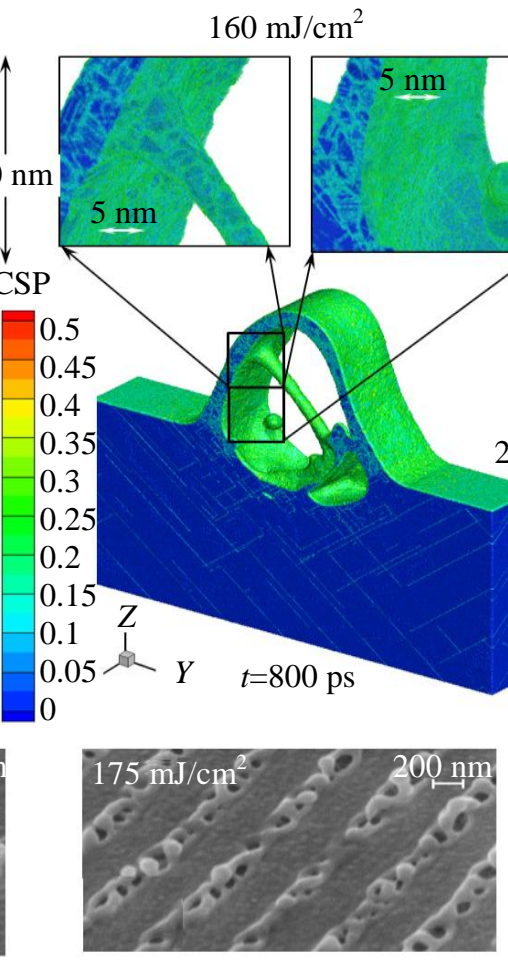

b

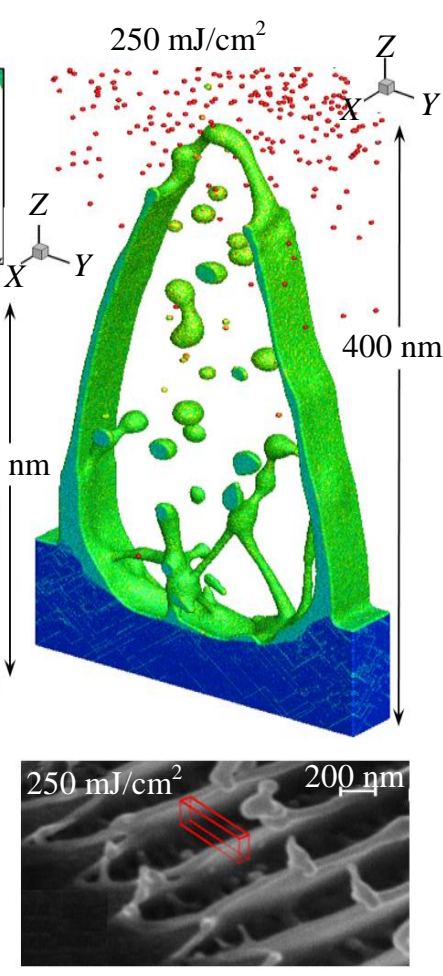

C

Fig. 7. The obtained in simulations final structures are directly compared [19] with the corresponding experimental SEM images of $270 \mathrm{~nm}$ periodic nanostructuring of gold targets with three different average incident fluences shown in columns for $130 \mathrm{~mJ} / \mathrm{cm}^{2}$ (a), $160 \mathrm{~mJ} / \mathrm{cm}^{2}$ (b), and $250 \mathrm{~mJ} / \mathrm{cm}^{2}$ (c). For the case (a), the obtained structure was treated by Focused Ion Beam (FIB) method to prepare a cross section, shown in Transmission Electron Microscopy (TEM) image for visualization of the internal structures in the center of (a). For the case (b), the areas of the atomic snapshot in black rectangles are zoomed for better visualization of the obtained internal polycrystalline structures. The red rectangle on the SEM image in (c) shows the relative position of the computational cell when simulating the nanostructuring process. In all atomic snapshots, taken at the final time of

$1000 \mathrm{ps}$, the atoms are colored according the CSP indicating gaseous atoms (red), surface (green), liquid ambient (light blue), dislocation planes and defects (blue), and the atoms with crystalline surrounding (dark blue)

\section{Conclusion}

Rapid expansion of the domain of practical applications of ultrashort pulse lasers into new areas where precise nanoscale control of the material modification is required can only be sustained with an improved fundamental understanding of laser-materials interactions. The ability to achieve high spatial resolution with UV laser pulses in material modification and microstructure engineering usually relies on fast and highly localized energy deposition that, unavoidably, creates the conditions of strong electronic, thermodynamic, and mechanical nonequilibrium.

Theoretical and computational description of the materials behavior far from the equilibrium is challenging and requires the revision of existing (or development of new) theoretical models and computational approaches. In particular, the intricate connections between the ultrafast material response to the laser excitation, generation of crystal defects, phase transformations, and mass transfer occurring under highly nonequilibrium conditions can only be accounted for by combining the research expertise and theoretical approaches. Close interdisciplinary collaborations and innovative design of new multiscale approaches (such as MD-TTM model) incorporating dissimilar physical concepts and operating at different time- and length-scales are needed for making a significant progress in the theoretical and computational description of laser-material interactions. 
The presented work revealed one of the concepts of the internal structures formation on the example of nanocrystalline character of the structures, obtained in the periodic nanostructuring experiments with short UV laser pulses. The applied MD-based model allowed for the direct comparison of the simulated and experimental results and revealed their close match. The demonstrated approach, therefore, opens the way to predict properties of surface modifications for industrial applications. This fact emphasizes that the understanding of these processes on an atomic scale and being able to precisely simulate them provides a powerful tool for designing new nano-technology applications.

\section{Литература}

1. Chichkov B.N., Momma C., Nolte S., von Alvensleben F., Tünnermann A. Femtosecond, picosecond and nanosecond laser ablation of solids // Applied Physics A. 1996. V. 63. P. 109-115. doi: 10.1007/bf01567637

2. Gattass R.R., Mazur E. Femtosecond laser micromachining in transparent materials // Nature Photonics. 2008. V. 2. P. 219225. doi: $10.1038 /$ nphoton. 2008.47

3. Vorobyev A.Y., Guo C. Direct femtosecond laser surface nano/microstructuring and its applications // Laser and Photonics Reviews. 2013. V. 7. P. 385-407. doi: 10.1002/lpor.201200017

4. Lin B., Elsayed-Ali H.E. Temperature dependent reflection electron diffraction study of $\operatorname{In}\left(\begin{array}{lll}1 & 1 & 1\end{array}\right)$ and observation of laserinduced transient surface superheating // Surface Science. 2002. V. 498. N 3. P. 275-284. doi: 10.1016/s00396028(01)01764-2

5. Siwick B.J., Dwyer J.R., Jordan R.E., Miller R.J.D. An atomiclevel view of melting using femtosecond electron diffraction // Science. 2003. V. 302. N 5649. P. 1382-1385. doi: 10.1126/science.1090052

6. Sokolowski-Tinten K., Blome C., Blums J., Cavalleri A., Dietrich C. et. al. Femtosecond X-ray measurement of coherent lattice vibrations near the Lindemann stability limit // Nature. 2003. V. 422. N 6929. P. 287-289. doi: 10.1038/nature01490

7. Ivanov D.S., Zhigilei L.V. Kinetic limit of heterogeneous melting in metals // Physical Review Letters. 2007. V. 98. N 19. Art. 195701. doi: 10.1103/physrevlett.98.195701

8. Lin Z., Leveugle E., Bringa E.M., Zhigilei L.V. Molecular dynamics simulation of laser melting of nanocrystalline $\mathrm{Au} / /$ The Journal of Physical Chemistry C. 2010. V. 114. N 12. P. 5686-5699. doi: 10.1021/jp909328q

9. Ivanov D.S., Lin Z., Rethfeld B., O'Connor G.M., Glynn Th.J., Zhigilei L.V. Nanocrystalline structure of nanobump generated by localized photoexcitation of metal film // Journal of Applied Physics. 2010. V. 107. N 1. P. 013519. doi: 10.1063/1.3276161

10. Pronko P.P., Dutta S.K., Squier J., Rudd J.V., Du D., Mourou G. Machining of sub-micron holes using a femtosecond laser at 800nm // Optics Communications. 1995. V. 114. N1-2. P. 106110. doi: 10.1016/0030-4018(94)00585-i

11. Koch J., Korte F., Bauer T., Fallnich C., Ostendorf A., Chichkov B.N. Nanotexturing of gold films by femtosecond laser-induced melt dynamics // Applied Physics A. 2005. V. 81. N 2. P. 325-328. doi: 10.1007/s00339-005-3212-6

12. Hwang D., Ryu S.-G., Misra N., Jeon H., Grigoropoulos C.P. Nanoscale laser processing and diagnostics // Applied Physics A. 2009. V. 96. N 2. P. 289-306. doi: 10.1007/s00339-0095207-1

13. Huber C., Trügler A., Hohenester U., Prior Y., Kautek W. Optical near-field excitation at commercial scanning probe microscopy tips: a theoretical and experimental investigation // Phys. Chem. Chem. Phys. 2014. V. 16. N 6. P. 2289-2296. doi: 10.1039/c3cp51730f

14. Ivanov D.S., Zhigilei L.V. Combined atomistic-continuum modeling of short-pulse laser melting and disintegration of metal films // Physical Review B. 2003. V. 68. N 6. Art. 064114. doi: 10.1103/physrevb.68.064114

15. Анисимов С.И., Капелиович Б.Л., Перельман Т.Л. Электронная эмиссия с поверхности металлов под действием ультракоротких лазерных импульсов // ЖЭТФ. 1974. T. 66. № 2. C. 776-781

16. Leveugle E., Ivanov D.S., Zhigilei L.V. Photochemical spallation of molecular and metal targets: molecular dynamic study // Applied Physics A. 2004. V. 79. N 1. P. 1643-1655. doi: 10.1007/s00339-004-2682-2

\section{References}

1. Chichkov B.N., Momma C., Nolte S., von Alvensleben F., Tünnermann A. Femtosecond, picosecond and nanosecond laser ablation of solids. Applied Physics A, 1996, vol. 63, pp. 109-115. doi: 10.1007/bf01567637

2. Gattass R.R., Mazur E. Femtosecond laser micromachining in transparent materials. Nature Photonics, 2008, vol. 2, pp. 219225. doi: 10.1038/nphoton.2008.47

3. Vorobyev A.Y., Guo C. Direct femtosecond laser surface nano/microstructuring and its applications. Laser and Photonics Reviews, 2013, vol. 7, pp. 385-407. doi: 10.1002/lpor.201200017

4. Lin B., Elsayed-Ali H.E. Temperature dependent reflection electron diffraction study of $\operatorname{In}\left(\begin{array}{lll}1 & 1 & 1\end{array}\right)$ and observation of laserinduced transient surface superheating. Surface Science, 2002, vol. 498, no. 3, pp. 275-284. doi: 10.1016/s00396028(01)01764-2

5. Siwick B.J., Dwyer J.R., Jordan R.E., Miller R.J.D. An atomiclevel view of melting using femtosecond electron diffraction. Science, 2003, vol. 302, no. 5649, pp. 1382-1385. doi: 10.1126/science.1090052

6. Sokolowski-Tinten K., Blome C., Blums J., Cavalleri A., Dietrich C. et. al. Femtosecond X-ray measurement of coherent lattice vibrations near the Lindemann stability limit. Nature, 2003, vol. 422, no. 6929, pp. 287-289. doi: 10.1038 /nature 01490

7. Ivanov D.S., Zhigilei L.V. Kinetic limit of heterogeneous melting in metals. Physical Review Letters, 2007, vol. 98, no. 19, art. 195701. doi: 10.1103/physrevlett.98.195701

8. Lin Z., Leveugle E., Bringa E.M., Zhigilei L.V. Molecular dynamics simulation of laser melting of nanocrystalline $\mathrm{Au}$. The Journal of Physical Chemistry C, 2010, vol. 114, no. 12, pp. 5686-5699. doi: 10.1021/jp909328q

9. Ivanov D.S., Lin Z., Rethfeld B., O'Connor G.M., Glynn Th.J., Zhigilei L.V. Nanocrystalline structure of nanobump generated by localized photoexcitation of metal film. Journal of Applied Physics, 2010, vol. 107, no. 1, pp. 013519. doi: 10.1063/1.3276161

10. Pronko P.P., Dutta S.K., Squier J., Rudd J.V., Du D., Mourou G. Machining of sub-micron holes using a femtosecond laser at 800nm. Optics Communications, 1995, vol. 114, no. 1-2, pp. 106-110. doi: 10.1016/0030-4018(94)00585-i

11. Koch J., Korte F., Bauer T., Fallnich C., Ostendorf A., Chichkov B.N. Nanotexturing of gold films by femtosecond laser-induced melt dynamics. Applied Physics A, 2005, vol. 81, no. 2, pp. 325-328. doi: 10.1007/s00339-005-3212-6

12. Hwang D., Ryu S.-G., Misra N., Jeon H., Grigoropoulos C.P. Nanoscale laser processing and diagnostics. Applied Physics A, 2009, vol. 96, no. 2, pp. 289-306. doi: 10.1007/s00339-0095207-1

13. Huber C., Trügler A., Hohenester U., Prior Y., Kautek W. Optical near-field excitation at commercial scanning probe microscopy tips: a theoretical and experimental investigation. Phys. Chem. Chem. Phys., 2014, vol. 16, no. 6, pp. 2289-2296. doi: $10.1039 / \mathrm{c} 3 \mathrm{cp} 51730 \mathrm{f}$

14. Ivanov D.S., Zhigilei L.V. Combined atomistic-continuum modeling of short-pulse laser melting and disintegration of metal films. Physical Review B, 2003, vol. 68, no. 6, art. 064114. doi: 10.1103/physrevb.68.064114

15. Anisimov S.I., Kapeliovich B.L., Perel'man T.L. Electron emission from metal surfaces exposed to ultrashort laser pulses. Journal of Experimental and Theoretical Physics, 1974, vol. 39, no. 2, pp. 375-377.

16. Leveugle E., Ivanov D.S., Zhigilei L.V. Photochemical spallation of molecular and metal targets: molecular dynamic 
17. Zhigilei L.V., Lin Z., Ivanov D.S. Atomistic modeling of short pulse laser ablation of metals: connections between melting, spallation, and phase explosion // The Journal of Physical Chemistry C. 2009. V. 113. N 27. P. 11892-11906. doi: 10.1021/jp902294m

18. Ivanov D.S., Lipp V.P., Rethfeld B., Garcia M.E. Moleculardynamics study of the mechanism of short-pulse laser ablation of single-crystal and polycrystalline metallic targets // Journal of Optical Technology. 2014. V. 81. N 5. P. 250-253. doi: 10.1364/jot.81.000250

19. Ivanov D.S., Lipp V.P., Blumenstein A., Veiko V.P., Yakovlev E.B. et. al. Experimental and theoretical investigation of periodic nanostructuring of $\mathrm{Au}$ with UV laser near the ablation threshold // Physical Review Applied. 2015. V. 4. N 6. Art. 064006. doi: 10.1103/physrevapplied.4.064006

20. Иванов Д.С., Липп В.П., Блюменштейн А., Вейко В.П., Яковлев Е.Б., Роддатис В.В., Гарсия М.Е., Ретфельд Б., Илеманн Ю., Симон П. Анализ образования периодических наноструктур на поверхности золота при воздействии лазерных ультракоротких импульсов вблизи порога плавления // Научно-технический вестник информационных технологий, механики и оптики. 2015. Т. 15. № 6. C. 984-999.

21. Corkum P.B., Brunel F., Sherman N.K., Srinivasan-Rao T. Thermal response of metals to ultrashort-pulse laser excitation // Physical Review Letters. 1988. V. 61. N 25. P. 2886-2889. doi: 10.1103/physrevlett.61.2886

22. Demsar J., Averitt R.D., Ahn K.H., Graf M.J., Trugman S.A., Kabanov V.V., Sarrao J.L., Taylor A.J. Quasiparticle relaxation dynamics in heavy fermion compounds // Physical Review Letters. 2003. V. 91. N 2. Art. 027401. doi: 10.1103/physrevlett.91.027401

23. Hohlfeld J., Wellershoff S.-S., Güdde J., Conrad U., Jähnke V., Matthias E. Electron and lattice dynamics following optical excitation of metals // Chemical Physics. 2000. V. 251. N 1-3. P. 237-258. doi: 10.1016/s0301-0104(99)00330-4

24. Ihlemann J., Klein-Wiele J.-H., Bekesi J., Simon P. UV ultrafast laser processing using phase masks // Journal of Physics: Conference Series. 2007. V. 59. P. 449-452. doi: 10.1088/1742-6596/59/1/096

25. Bekesi J., Simon P., Ihlemann J. Deterministic sub-micron 2D grating structures on steel by UV-fs-laser interference patterning // Applied Physics A. 2014. V. 114. N 1. P. 69-73. doi: 10.1007/s00339-013-8083-7

26. Borchers B., Bekesi J., Simon P., Ihlemann J. Submicron surface patterning by laser ablation with short UV pulses using a proximity phase mask setup // Journal of Applied Physics. 2010. V. 107. N 6. Art. 063106. doi: 10.1063/1.3331409

27. Eisele C., Nebel C.E., Stutzmann M. Periodic light couple gratings in amorphous thin film solar cells // Journal of Applied Physics. 2001. V. 89. N 12. P. 7722-7726. doi: 10.1063/1.1370996

28. Chen J.-T., Lai W.-C., Kao Y.-J, Yang Y.-Y., Sheu J.-J. Laserinduced periodic structures for light extraction efficiency enhancement of GaN-based light emitting diodes // Optics Express. 2012. V. 20. N 5. P. 5689-5695. doi: 10.1364/oe.20.005689

29. Wang C., Chang Y.-C., Yao J., Luo C., Yin S., Ruffin P., Brantley C., Edwards E. Surface enhanced Raman spectroscopy by interfered femtosecond laser created nanostructures // Applied Physics Letters. 2012. V. 100. N 2. Art. 023107. doi: 10.1063/1.3676040

30. Nagy T., Simon P. Single-shot TG FROG for the characterization of ultrashort DUV pulses // Optics Express. 2009. V. 17. N 10. P. 8144-8151. doi: 10.1364/oe.17.008144

31. Ivanov D.S., Rethfeld B., O'Connor G.M., Glynn T.J., Volkov A.N., Zhigilei L.V. The mechanism of nanobump formation in femtosecond pulse laser nanostructuring of thin metal films // Applied Physics A. 2008. V. 92. N 4. P. 791-796. doi: 10.1007/s00339-008-4712-y

32. Ivanov D.S., Kuznetsov A.I., Lipp V.P., Rethfeld B., Chichkov B.N., Garcia M.E., Schulz W. Short laser pulse nanostructuring of metals: direct comparison of molecular dynamics modeling and experiment // Applied Physics A. 2013. V. 111. N 3. P. 675-687. doi: 10.1007/s00339-013-7656-9

33. Schäfer C., Urbassek H.M., Zhigilei L.V., Garrison B.J. study. Applied Physics A, 2004, vol. 79, no. 1, pp. 1643-1655. doi: 10.1007/s00339-004-2682-2

17. Zhigilei L.V., Lin Z., Ivanov D.S. Atomistic modeling of short pulse laser ablation of metals: connections between melting, spallation, and phase explosion. The Journal of Physical Chemistry C, 2009, vol. 113, no. 27, pp. 11892-11906. doi: 10.1021/jp902294m

18. Ivanov D.S., Lipp V.P., Rethfeld B., Garcia M.E. Moleculardynamics study of the mechanism of short-pulse laser ablation of single-crystal and polycrystalline metallic targets. Journal of Optical Technology, 2014, vol. 81, no. 5, pp. 250-253. doi: 10.1364/jot.81.000250

19. Ivanov D.S., Lipp V.P., Blumenstein A., Veiko V.P., Yakovlev E.B. et. al. Experimental and theoretical investigation of periodic nanostructuring of $\mathrm{Au}$ with UV laser near the ablation threshold. Physical Review Applied, 2015, vol. 4, no. 6, art. 064006. doi: 10.1103/physrevapplied.4.064006

20. Ivanov D.S., Lipp V.P., Blumenstein A., Veiko V.P., Yakovlev E.B., Roddatis V.V., Garcia M.E., Rethfeld B., Ihlemann J., Simon P. Analysis of periodic nanostructures formation on a gold surface under exposure to ultrashort laser pulses near the melting threshold. Scientific and Technical Journal of Information Technologies, Mechanics and Optics, 2015, vol. 15, no. 6, pp. 984-999. (in Russian).

21. Corkum P.B., Brunel F., Sherman N.K., Srinivasan-Rao T. Thermal response of metals to ultrashort-pulse laser excitation. Physical Review Letters, 1988, vol. 61, no. 25, pp. 2886-2889. doi: 10.1103/physrevlett.61.2886

22. Demsar J., Averitt R.D., Ahn K.H., Graf M.J., Trugman S.A., Kabanov V.V., Sarrao J.L., Taylor A.J. Quasiparticle relaxation dynamics in heavy fermion compounds. Physical Review Letters, 2003, vol. 91, no. 2, art. 027401. doi: 10.1103/physrevlett.91.027401

23. Hohlfeld J., Wellershoff S.-S., Güdde J., Conrad U., Jähnke V., Matthias E. Electron and lattice dynamics following optical excitation of metals. Chemical Physics, 2000, vol. 251, no. 1-3, pp. 237-258. doi: 10.1016/s0301-0104(99)00330-4

24. Ihlemann J., Klein-Wiele J.-H., Bekesi J., Simon P. UV ultrafast laser processing using phase masks. Journal of Physics: Conference Series, 2007, vol. 59, pp. 449-452. doi: 10.1088/1742-6596/59/1/096

25. Bekesi J., Simon P., Ihlemann J. Deterministic sub-micron 2D grating structures on steel by UV-fs-laser interference patterning. Applied Physics A. 2014, vol. 114, no. 1, pp. 69-73. doi: 10.1007/s00339-013-8083-7

26. Borchers B., Bekesi J., Simon P., Ihlemann J. Submicron surface patterning by laser ablation with short UV pulses using a proximity phase mask setup. Journal of Applied Physics, 2010, vol. 107, no. 6, art. 063106. doi: 10.1063/1.3331409

27. Eisele C., Nebel C.E., Stutzmann M. Periodic light coupler gratings in amorphous thin film solar cells. Journal of Applied Physics, 2001, vol. 89, no. 12, pp. 7722-7726. doi: 10.1063/1.1370996

28. Chen J.-T., Lai W.-C., Kao Y.-J, Yang Y.-Y., Sheu J.-J. Laserinduced periodic structures for light extraction efficiency enhancement of GaN-based light emitting diodes. Optics Express, 2012, vol. 20, no. 5, pp. 5689-5695. doi: 10.1364/oe.20.005689

29. Wang C., Chang Y.-C., Yao J., Luo C., Yin S., Ruffin P., Brantley C., Edwards E. Surface enhanced Raman spectroscopy by interfered femtosecond laser created nanostructures. Applied Physics Letters, 2012, vol. 100, no. 2, art. 023107. doi: 10.1063/1.3676040

30. Nagy T., Simon P. Single-shot TG FROG for the characterization of ultrashort DUV pulses. Optics Express, 2009, vol. 17, no. 10, pp. 8144-8151. doi: 10.1364/oe.17.008144

31. Ivanov D.S., Rethfeld B., O'Connor G.M., Glynn T.J., Volkov A.N., Zhigilei L.V. The mechanism of nanobump formation in femtosecond pulse laser nanostructuring of thin metal films. Applied Physics A, 2008, vol. 92, no. 4, pp. 791-796. doi: 10.1007/s00339-008-4712-y

32. Ivanov D.S., Kuznetsov A.I., Lipp V.P., Rethfeld B., Chichkov B.N., Garcia M.E., Schulz W. Short laser pulse nanostructuring of metals: direct comparison of molecular dynamics modeling and experiment. Applied Physics A, 2013, vol. 111, no. 3, pp. 
Pressure-transmitting boundary conditions for molecular dynamics simulations // Computational Materials Science. 2002. V. 24. N 4. P. 421-429. doi: 10.1016/s09270256(01)00263-4

34. Zhakhovskii V.V., Inogamov N.A., Petrov Yu.V., Ashitkov S.I., Nishihara K. Molecular dynamics simulation of femtosecond ablation and spallation with different interatomic potentials // Applied Surface Science. 2009. V. 255. N 24. P. 9592-9596. doi: 10.1016/j.apsusc.2009.04.082

35. Smithell's Metal Reference Book. $8^{\text {th }}$ ed. / Eds. W.F. Gale, T.C. Totemeier. Butterworth-Heinemann, Oxford, 2004. 2080 p.

36. Ivanov D.S., Lipp V.P., Veiko V.P., Yakovlev E., Rethfeld B., Garcia M.E. Molecular dynamics study of the short laser pulse ablation: quality and efficiency in production // Applied Physics A. 2014. V. 117. N 4. P. 2133-2141. doi: 10.1007/s00339-014-8633-7

37. Wu B., Shin Y.C. A self-closed thermal model for laser shock peening under the water confinement regime configuration and comparisons to experiments // Journal of Applied Physics. 2005. V. 97. N 11. Art. 113517. doi: 10.1063/1.1915537

38. Nakano H., Miyauti S., Butani N., Shibayanagi T., Tsukamoto M., Abe N. Femtosecond laser peening of stainless steel // Journal of Laser Micro/Nanoengineering. 2009. V. 4. N 1. P. 35-38. doi: 10.2961/jlmn.2009.01.0007

39. Nakano H., Tsuyama M., Miyauti S., Shibayanagi T., Tsukamoto M., Abe N. Femtosecond and nanosecond laser peening of stainless steel // Journal of Laser Micro/Nanoengineering. 2010. V. 5. N 2. P. 175-178. doi: 10.2961/jlmn.2009.01.0007

40. Cheng G.J., Shehadeh M.A. Dislocation behavior in silicon crystal induced by laser shock peening: a multiscale simulation approach // Scripta Materialia. 2005. V. 53. N 9. P. 1013-1018. doi: 10.1016/j.scriptamat.2005.07.014

41. Wu C., Zhigilei L.V. Nanocrystalline and polyicosahedral structure of a nanospike generated on metal surface irradiated by a single femtosecond laser pulse // Journal of Physical Chemistry C. 2016. V. 120. N 8. P. 4438-4447. doi: $10.1021 /$ acs.jpcc.6b00013

42. Valiev R.Z., Islamgaliev R.K., Alexandrov I.V. Bulk nanostructured materials from severe plastic deformation // Progress in Materials Science. 2000. V. 45. N 2. P. 103-189. doi: 10.1016/s0079-6425(99)00007-9

43. Bufford D.C., Morris Wang Y., Liu Y., Li L. Synthesis and microstructure of electrodeposited and sputtered nanotwinned face-centered-cubic metals // MRS Bulletin. 2016. V. 41. N 4. P. 286-291. doi: $10.1557 / \mathrm{mrs} .2016 .62$

44. Fang T.H., Li W.L., Tao N.R., Lu K. Revealing extraordinary intrinsic tensile plasticity in gradient nano-grained copper // Science. 2011. V. 331. N 6024. P. 1587-1590. doi: $10.1126 /$ science. 1200177

45. Jang D., Li X., Gao H., Greer J.R. Deformation mechanisms in nanotwinned metal nanopillars // Nature Nanotechnology. 2012. V. 7. N 9. P. 594-601. doi: 10.1038/nnano.2012.116

46. Li X., Dao M., Eberl C., Hodge A.M., Gao H. Fracture, fatigue, and creep of nanotwinned metals // MRS Bulletin. 2016. V. 41. N 4. P. 298-304. doi: $10.1557 / \mathrm{mrs} .2016 .65$

47. Ivanov D.S., Rethfeld B.C. The effect of pulse duration on the interplay of electron heat conduction and electron-phonon interaction: photo-mechanical versus photo-thermal damage of metal targets // Applied Surface Science. 2009. V. 255. N 24. P. 9724-9728. doi: 10.1016/j.apsusc.2009.04.131

48. Иногамов Н.А., Жаховский В.В., Ашитков С.И., Петров Ю.В., Агранат М.Б., Анисимов С.И., Нишихара К., Фортов В.Е. О наноотколе после воздействия ультракороткого лазерного импульса // ЖЭТФ. 2008. Т. 134. № 1. С. 1-29.

49. Upadhyay A.K., Inogamov N.A., Rethfeld B., Urbassek H.M. Ablation by ultrashort laser pulses: atomistic and thermodynamic analysis of the processes at the ablation threshold // Physical Review B. 2008. V. 78. N 4. Art. 045437. doi: 10.1103/physrevb.78.045437

50. Wellershoff S.-S., Hohlfeld J., Güdde J., Matthias E. The role of electron-phonon coupling in femtosecond laser damage of metals // Applied Physics A. 1999. V. 69. P. S99-S107. doi: 10.1007/s003399900305

51. Veiko V.P., Shakhno E.A., Yakovlev E.B. Effective time of thermal effect of ultrashort laser pulses on dielectrics //
675-687. doi: 10.1007/s00339-013-7656-9

33. Schäfer C., Urbassek H.M., Zhigilei L.V., Garrison B.J. Pressure-transmitting boundary conditions for molecular dynamics simulations. Computational Materials Science, 2002, vol. 24, no. 4 , pp. 421-429. doi: 10.1016/s09270256(01)00263-4

34. Zhakhovskii V.V., Inogamov N.A., Petrov Yu.V., Ashitkov S.I., Nishihara K. Molecular dynamics simulation of femtosecond ablation and spallation with different interatomic potentials. Applied Surface Science, 2009, vol. 255, no. 24, pp. 9592-9596. doi: 10.1016/j.apsusc.2009.04.082

35. Smithell's Metal Reference Book. $8^{\text {th }}$ ed. Eds. W.F. Gale, T.C. Totemeier. Butterworth-Heinemann, Oxford, 2004, 2080 p.

36. Ivanov D.S., Lipp V.P., Veiko V.P., Yakovlev E., Rethfeld B., Garcia M.E. Molecular dynamics study of the short laser pulse ablation: quality and efficiency in production. Applied Physics A, 2014, vol. 117, no. 4, pp. 2133-2141. doi: 10.1007/s00339014-8633-7

37. Wu B., Shin Y.C. A self-closed thermal model for laser shock peening under the water confinement regime configuration and comparisons to experiments. Journal of Applied Physics, 2005, vol. 97, no. 11, art. 113517. doi: 10.1063/1.1915537

38. Nakano H., Miyauti S., Butani N., Shibayanagi T., Tsukamoto M., Abe N. Femtosecond laser peening of stainless steel. Journal of Laser Micro/Nanoengineering, 2009, vol. 4, no. 1, pp. 35-38. doi: 10.2961/jlmn.2009.01.0007

39. Nakano H., Tsuyama M., Miyauti S., Shibayanagi T., Tsukamoto M., Abe N. Femtosecond and nanosecond laser peening of stainless steel. Journal of Laser Micro/Nanoengineering, 2010, vol. 5, no. 2, pp. 175-178. doi: 10.2961/jlmn.2009.01.0007

40. Cheng G.J., Shehadeh M.A. Dislocation behavior in silicon crystal induced by laser shock peening: a multiscale simulation approach. Scripta Materialia, 2005, vol. 53, no. 9, pp. 10131018. doi: $10.1016 /$ j.scriptamat.2005.07.014

41. Wu C., Zhigilei L.V. Nanocrystalline and polyicosahedral structure of a nanospike generated on metal surface irradiated by a single femtosecond laser pulse. Journal of Physical Chemistry C, 2016, vol. 120, no. 8, pp. 4438-4447. doi: 10.1021/acs.jpcc.6b00013

42. Valiev R.Z., Islamgaliev R.K., Alexandrov I.V. Bulk nanostructured materials from severe plastic deformation. Progress in Materials Science, 2000, vol. 45, no. 2, pp. 103189. doi: 10.1016/s0079-6425(99)00007-9

43. Bufford D.C., Morris Wang Y., Liu Y., Li L. Synthesis and microstructure of electrodeposited and sputtered nanotwinned face-centered-cubic metals. MRS Bulletin, 2016, vol. 41, no. 4, pp. 286-291. doi: $10.1557 / \mathrm{mrs} .2016 .62$

44. Fang T.H., Li W.L., Tao N.R., Lu K. Revealing extraordinary intrinsic tensile plasticity in gradient nano-grained copper. Science, 2011, vol. 331, no. 6024, pp. 1587-1590. doi: $10.1126 /$ science. 1200177

45. Jang D., Li X., Gao H., Greer J.R. Deformation mechanisms in nanotwinned metal nanopillars. Nature Nanotechnology, 2012, vol. 7, no. 9, pp. 594-601. doi: 10.1038/nnano.2012.116

46. Li X., Dao M., Eberl C., Hodge A.M., Gao H. Fracture, fatigue, and creep of nanotwinned metals. MRS Bulletin, 2016, vol. 41, no. 4, pp. 298-304. doi: 10.1557/mrs.2016.65

47. Ivanov D.S., Rethfeld B.C. The effect of pulse duration on the interplay of electron heat conduction and electron-phonon interaction: photo-mechanical versus photo-thermal damage of metal targets. Applied Surface Science, 2009, vol. 255, no. 24, pp. 9724-9728. doi: 10.1016/j.apsusc.2009.04.131

48. Inogamov N.A., Zhakhovskii V.V., Ashitkov S.I., Petrov Yu.V., Agranat M.B., Anisimov S.I., Nishihara K., Fortov V.E. Nanospallation induced by an ultrashort laser pulse. Journal of Experimental and Theoretical Physics, 2008, vol. 107, no. 1, pp. 1-19. doi: 10.1134/s1063776108070017

49. Upadhyay A.K., Inogamov N.A., Rethfeld B., Urbassek H.M. Ablation by ultrashort laser pulses: atomistic and thermodynamic analysis of the processes at the ablation threshold. Physical Review B, 2008, vol. 78, no. 4, art. 045437. doi: 10.1103/physrevb.78.045437

50. Wellershoff S.-S., Hohlfeld J., Güdde J., Matthias E. The role of electron-phonon coupling in femtosecond laser damage of metals. Applied Physics A, 1999, vol. 69, pp. S99-S107. doi: 
Quantum Electronics. 2014. V. 44. N 4. P. 322-324. doi: 10.1070/qe2014v044n04abeh015324

52. Wu C., Zhigilei L.V. Microscopic mechanisms of laser spallation and ablation of metal targets from large-scale molecular dynamics simulations // Applied Physics A. 2014. V. 114. N 1. P. 11-32. doi: 10.1007/s00339-013-8086-4

\section{Авторы}

Иванов Дмитрий Сергеевич - кандидат физико-технических наук, старший научный сотрудник, Университет Касселя, Кассель, 34132, Германия; старший научный сотрудник, Технический Университет Кайзерслаутерна, Кайзерслаутерн, 67663, Германия; научный руководитель международной лаборатории, Университет ИТМО, Санкт-Петербург, 197101 Российская Федерация, Ivanov@uni-kassel.de

Блюменитайн Андреас - аспирант, Лазерная лаборатория Гёттингена, Гёттинген, 37077, Германия; аспирант, Университет Касселя, Кассель, 34132, Германия, andreas.blumenstein@1lgev.de

Ретфельд Барбель - доктор технических наук, профессор, руководитель группы, Технический университет Кайзерслаутерна, Кайзерслаутерн, 67663, Германия, rethfeld@physik.uni-kl.de

Вейко Вадим Павлович - доктор технических наук, профессор заведующий кафедрой, Университет ИТМО, Санкт-Петербург, 197101, Российская Федерация, veiko@lastech.ifmo.ru

Яковлев Евгений Борисович - доктор технических наук, доцент профессор, Университет ИТМО, Санкт-Петербург, 197101 Российская Федерация, yak@lastech.ifmo.ru

Гарсия Мартин Эзекель - $\mathrm{PhD}$, профессор, профессор, Университет Касселя, Кассель, 34132, Германия, garcia@physik.uni-kassel.de

Симон Питер - доктор технических наук, руководитель отдела короткоимпульсной фотоники, Лазерная лаборатория Гёттингена, Гёттинген, 37077, Германия, peter.simon@llg-ev.de Илеман Юрген - доктор технических наук, старший научный сотрудник, Лазерная лаборатория Гёттингена, Гёттинген, 37077, Германия, juergen.ihlemann@llg-ev.de

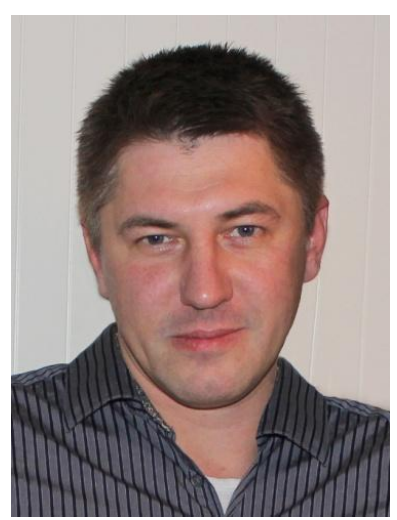

Дмитрий Сергеевич Иванов окончил в 1997 г. физико-технический факультет СанктПетербургского политехнического университета Петра Великого по специальности «Космические исследования». В 2004 г. получил ученую степень PhD в Университете Виргинии (США). В настоящее время работает старшим научным сотрудником Технического университета г. Кайзерслаутерна и Университета г. Кассель в Германии. С 2015 г. - соруководитель международной лаборатории «Лазерные микро- и нанотехнологии» при Университете информационных технологий, механики и оптики (Университете ИТМО) г. Санкт-Петербург. Область научных интересов включает в себя моделирование процессов короткоимпульсного лазерного плавления, спаляции, абляции и наноструктурирования на поверхностях металлов, полупроводников и диэлектриков.

Dmitry S. Ivanov graduated from Physico-Technical Department of Peter the Great St. Petersburg Politechnic University (Politech) in 1997 with specialization of "Space Research". In 2004 he obtained his PhD degree in the University of Virginia (USA). At present he works as a Senior Researcher at Technical University of Kaiserslautern and University of Kassel (Germany). Also, since 2015 he has been a co-chief of the International Laboratory of "Laser Microand Nanotechnologies" at Saint Petersburg State University of Information Technologies, Mechanics and Optics (Russia). His scientific research interests cover modeling of short laser pulse melting, spallation, ablation processes as well as laserinduced nanostructuring of metals, semiconductors, and dielectric surfaces.

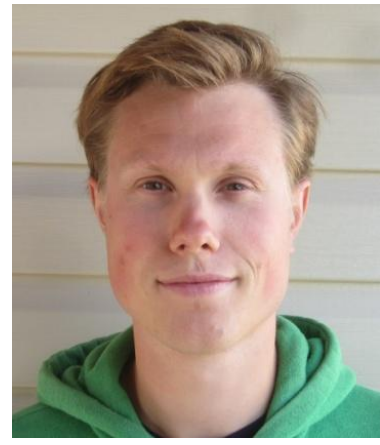

Андреас Блюменштайн получил степень магистра в Университете Гёттингена в 2013 г. Работал над проблемами отокатализа и самоорганизующихся наноструктур. В настоящее время - аспирант Лазерной лаборатории Гёттингена и Университета города Кассель (Германия). Область научных интересов включает в себя лазерное структурирование поверхностей материалов и нелинейную оптику.

Andreas Blumenstein received a Master of Science degree from the University of Göttingen in 2013 working on photo-catalysis and self-assembled nano-structuring. He is currently doing his $\mathrm{PhD}$ at the Laser-Laboratorium Göttingen e.V. and the University of Kassel. Scientific interests are: laser surface structuring, nonlinear optics, solid state physics. 


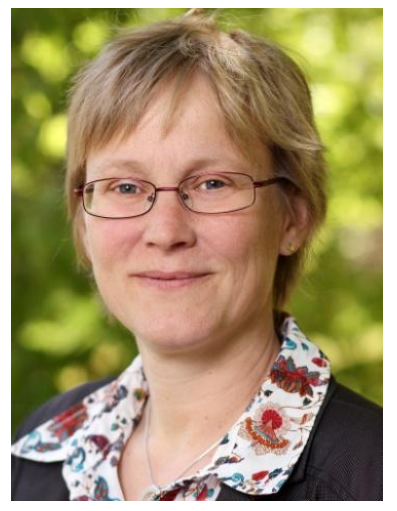

Барбель Ретфельд - доктор наук. С 2013 г. - профессор отделения Прикладной и теоретической физики Университета г. Кайзерслаутерн. В 1999 г. получила ученую степень $\mathrm{PhD}$ в Университете г. Брауншвайг. Профессор Ретфельд работала в Университете г. Эссен (Германия), Московском институте теоретической физики им Л.Д. Ландау и в Центре по изучению тяжелых ионов им. Гельмгольца (Дармштадт, Германия). Основала собственную исследовательскую группу сверхбыстрой динамики материалов под воздействием лазерного излучения в Университете г. Кайзерслаутерн. Обладатель гранта им. Эмми Ноетер Германского исследовательского фонда DFG (Германия). Ocновное направление научной деятельности - теоретическое описание сверхбыстрой динамики твердых тел под воздействием лазерного излучения с акцентом на неравновесные процессы.

Barbel Rethfeld is a Heisenberg Professor of Applied Theoretical Physics at the University of Kaiserslautern since 2013. She received her PhD degree from the University of Braunschweig in 1999 and has worked since then at the University of Essen, Germany, L.D. Landau Institute for Theoretical Physics in Moscow, Russia, and GSI Helmholtz Institute in Darmstadt, Germany.In 2007 she established her own research group at the University of Kaiserslautern, after she was awarded an Emmy Noether grant from the German Research Foundation (DFG). Her research interest is in the theoretical description of ultrafast dynamics of laserexcited solids with an emphasis on nonequilibrium processes.

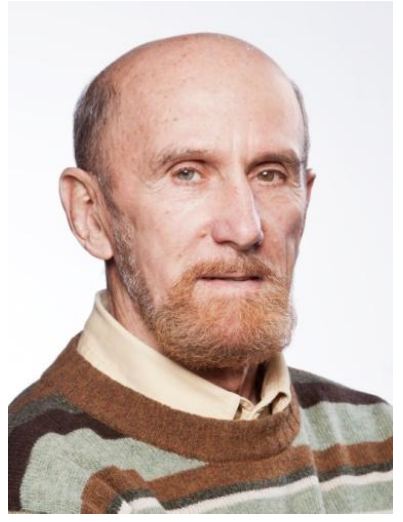

Вадим Павлович Вейко - доктор технических наук, профессор, заведующий кафедрой лазерных технологий и систем, заслуженный деятель науки Российской Федерации, лауреат Государственной премии СССР в области науки (1986) и премии Правительства Российской федерации в области образования (2010). Руководитель международной научной лаборатории «Лазерные микро- и нанотехнологии». Область научных интересов - взаимодействие лазерного излучения с веществом, фундаментальные основы лазерных технологий. Автор более 300 работ, в том числе 12 монографий на русском, английском и китайском языках.

Vadim P. Veiko - D.Sc., Professor, Head of Laser Technologies and Systems Department of Saint Petersburg State University of Information Technologies, Mechanics, and Optics (ITMO University). He is an Honored scientist of the Russian Federation, USSR State Prize winner in the field of science (1986), RF Government Prize winner in the field of education (2010). He is a Head of the International Laboratory of "Laser Micro- and Nanotechnologies". His scientific research interests cover such fields like Laser-Mutter Interaction, Fundamentals of Laser Technologies, etc. He is the author and coauthor of more than 300 scientific publications, among them 12 monographs in Russian, English and Chinese.

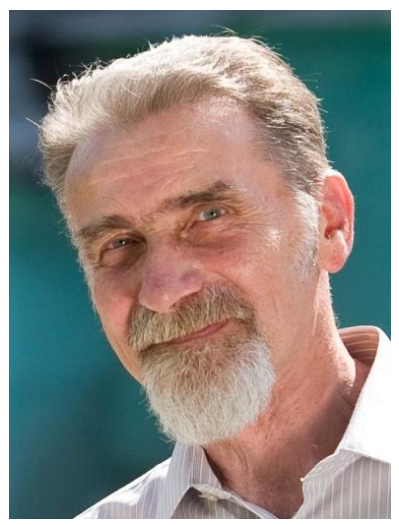

Евгений Борисович Яковлев - доктор технических наук, профессор кафедры Лазерных технологий и систем Университета ИТМО (г. Санкт-Петербург). Окончил Ленинградский институт точной механики и оптики. В 1985 г. защитил кандидатскую диссертацию по специальности «Физическая электроника, в том числе квантовая», а в 1999 г. - докторскую диссертацию по специальности «Оптические и оптикоэлектронные приборы». Награжден премиями Президиума АН СССР за лучшую научную работу по направлению «Фундаментальные проблемы микроэлектроники (1976 г.), Минвуза СССР за лучшую научную работу (1983 г.), Правительства РФ в области образования «Создание инновационной научно-образовательной системы подготовки кадров высшей квалификации в области лазерной технологии обработки материалов» (2010 г.). Член программного комитета серии международных конференций «Fundamentals of Laser Assisted Micro- and Nanotechnologies» (FLAMN). Область научных интересов - взаимодействие лазерного излучения с веществом, лазерные технологии. Автор более 160 научных и методических работ, патентов. Главный редактор журнала «Известия вузов. Приборостроение», эксперт РАН.

Evgeniy B. Yakovlev - D.Sc., Professor of Laser Technologies and Systems Department of Saint Petersburg State University of Information Technologies, Mechanics and Optics (ITMO University). He has graduated from Leningrad Institute of Fine Mechanics and Optics. In 1985 he obtained his PhD degree with specialization of "Physical Electronics including Quantum One" and in 1999 he presented his habilitational thesis with specialization of "Optical and Optoelectron Devices". He was awarded with the Prizes of the Presidium of the Academy of Sciences of the USSR for the best scientific research in the direction of "Fundamental Problems of Microelectronics" in 1976, the USSR Ministry of Higher Education Institutions for the best scientific research in 1983, the Government of the Russian Federation in the field of education "Creation of innovative scientific educational system for key personnel training in the area of material processing laser technology" in 2010. He is a member of Program Committee for a number of international conferences «Fundamentals of Laser Assisted Micro- and Nanotechnologies» (FLAMN). His scientific interests are: Laser-Mutter Interaction, Laser Technologies. He is the author of more than 160 scientific and methodology works, patents. He is an Editor-in-Chief of the magazine "News of Higher Educational Institutions. Instrumentation", RAS Expert. 


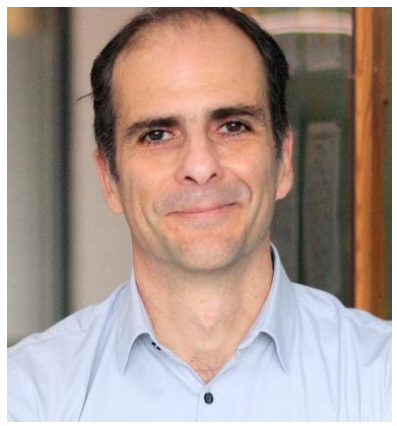

Мартин Е. Гарсия - профессор Университета г. Кассель, отделение математики и естественных наук. Окончил институт Балсейро (Барилоджи, Аргентина) в 1984 г. по специальности «Физика» и в 1992 г. защитил кандидатскую диссертацию (PhD) в Берлинском Университете. После работы младшим научным сотрудником (PostDoc) в Соединенных Штатах Америки и Испании вернулся в Берлинский Университет, где до 1999 г. проходил докторантуру на кафедре теоретической физики. Впоследствии занимал временные позиции профессора в Университете г. Грейсвальд (Германия) и приглашенного профессора в Испании и Мексике. В 2004 г. получил постоянную позицию профессора на отделении теоретической физики Университета г. Кассель (Германия). Там же с 2006 по 2008 гг. профессор Гарсия занимал должность заместителя декана на отделении естественных наук. Область его научных интересов обширна и включает в себя изучение электронных, оптических и диффузионных свойств твердых тел и наноструктур, процессов фазовых переходов, индуцированных лазерным излучением, биофизических процессов свертывания белков и межклеточной коммуникации.

Martin E. Garcia has studied Physics at the Instituto Balseiro, Bariloche, Argentina. He obtained his PhD in Physics at the Free University of Berlin in 1992. After PostDoc position in the USA and Spain he returned to the Free University, where he obtained his Habilitation in Theoretical Physics in 1999. A temporal appointment as a Professor at the University of Greifswald, Germany, followed. After positions as invited Professor in Spain and Mexico he obtained a permanent appointment as a Professor for Theoretical Physics at the University of Kassel, Germany in 2004. He was a Vice Dean of the Department of Natural Sciences between 2006 and 2008. His research interests are quite broad, ranging from electronic, optical and transport properties of solids and nanostructures, interaction of lasers with materials, laser induced phase transitions, up to Biophysics (protein folding and intercellular communication)

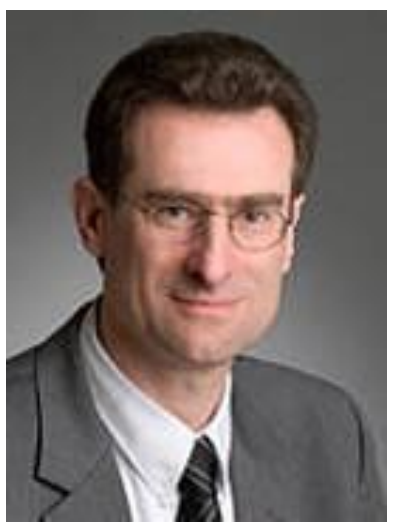

Питер Симон - руководитель отдела "Коротких импульсов и наноструктур”Лазерной Лабортории Геттингена, Германия. В целом, его исследования направлены на применение сверхкоротких лазерных импульсов в создании экстримальных концентраций энергии в пространстве и времени. Подобные источники энергии позволяют генерировать крайне высокие интенсивности при достаточно умеренной доставляемой энергии и с высокой степенью контроля. Благодаря этому, сверхкороткие лазерные импульсы обладают огромным потенциалом для применений в современных технологических процесcax. Предмет его текущих исследований включает в себя генерацию и копрессию лазерных импульсов с высокой энергией и длинной в несколько периодов, а также субмикронная структуризация поверхностей технологических материалов.

Peter Simon is a head of the Department 'Short Pulses / Nanostructures' at the Laser Laboratory Goettingen, Germany. His research in general is devoted to the usage of ultrashort lasers pulses and their ability for extreme concentration of energy in time and space. Such sources allow the generation of very high intensities while delivering only moderate energies in a well-controlled manner. Therefore the ultrashort-pulse laser technology holds great potential for applications in a row of contemporary technology branches. The subjects of his current research include the generation and compression of energetic few-cycle pulses, and the submicron-scale surface texturing of technical materials.

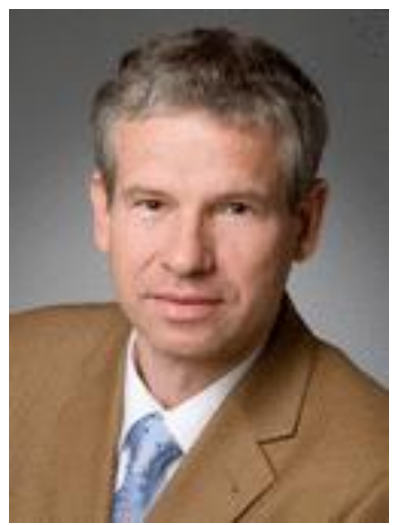

Юрген Илеман - старший научный сотрудник Лазерной Лаборатории Геттингена, Германия. Защитил диплом по специальности физика в 1984г. и в 1987г. получил ученую степень PhD по физичечкой химии в университете Геттингена. C 1984 по 1988 года работал Институте Биофизической Химии Макс-Планка в Геттингене, где занимался пикосекундной лазерной спектроскопией. В 1989г. начал работу в Лазерной Лаборатории Геттингена, где изучал образование периодических наноструктур, сгенерированных короткоимпульсным лазерным излучением, что остается основным направлением исследований Юргена Илемана по настоящее время. Образование таких структур на поверхности металлов, полупроводников, диэлектриков или полимеров может приводить к получению материалов с новыми уникальными свойствами или с особыми електрическими или механическими характеристиками в частности. В зависимости от свойств материала и морфологии получаемых структур, могут быть реализованы новые устройства такие как: микро-лазеры, оптические нано-переключатели, оптические устройства хранения информации, био-сенсоры или генераторы защиты прав производителя. Более того, получаемые наноструктурированные поверхности могут быть использованы для улучшения трибологический свойств материалов, для уменьшения потерь вызываемых отражением, для изменения смачиваемости, в биотехнологиях или в ювелирных работах.

Juergen Ihlemann is a senior research scientist at the Laser Laboratory Goettingen, Germany. He received his diploma in physics (1984) and Ph.D. in physical chemistry (1987) from the University of Göttingen. From 1984 to 1988 he was with the Max-Planck-Institute for biophysical chemistry, Göttingen, where he was working on picosecond laser spectroscopy. In 1989 he joined Laser-Laboratorium Göttingen, where the study of ultrashort laser pulse generated periodic nanostructures became one of the main topics of his present research.Such structures on the surface of metals, semiconductors, dielectrics or polymers can generate new unique material properties with very special electrical or mechanical characteristics. Depending on the specific material parameters and the morphology of the structures, new devices like micro-lasers, optical nanoswitches, optical storage devices, bio-sensors or anti-fraud features can be realized. Furthermore, surface textures can be used to improve the tribological properties of special tools, for the reduction of reflection losses, to modify the wettability or the cell growth properties or as decoration elements for the refinement of precious goods. 